\title{
Calculation of Groundwater Discharge to the Columbia River in the 100-N Area
}

\author{
T. J. Gilmore \\ D. R. Newcomer \\ S. K. Wurstner \\ F. A. Spane
}

April 1992

Prepared for the U.S. Department of Energy under Contract DE-AC06-76RLO 1830

Pacific Northwest Laboratory Operated for the U.S. Department of Energy by Battelle Memorial Institute 


\title{
DISCLAIMER
}

This report was prepared as an account of work sponsored by an agency of the United States Government. Neither the United States Government nor any agency thereof, nor Battelle Memorial Institute, nor any of their employees, makes any warranty, expressed or implied, or assumes any legal liability or responsibility for the accuracy, completeness, or usefulness of any information, apparatus, product, or process disclosed, or represents that its use would not infringe privately owned rights. Reference herein to any specific commercial product, process, or service by trade name, trademark, manufacturer, or otherwise does not necessarily constitute or imply its endorsement, recommendation, or favoring by the United States Government or any agency thereof, or Battelle Memorial Institute. The views and opinions of authors expressed herein do not necessarily state or reflect those of the Uniled States Government or any agency thereof.

\author{
PACIFIC NORTHWEST LABORATORY \\ operated by \\ BATTELLE MEMORIAL INSTITUTE \\ for the \\ UNITED STATES DEPARTMENT OF ENERGY \\ under Contract DE-AC06-76RLO 1830
}

Printed in the United States of America

Available to DOE and DOE contractors from the

Office of Scientific and Technical Information, P.O. Box 62, Oak Ridge, IN 37831;

prices available from (615) 576-8401. FTS 626-8401.

Available to the public from the National Technical Information Service,

U.S. Department of Commerce, 5285 Port Royal Rd., Springfield, VA 22161. 
PNL-8057

UC -903

CALCULATION OF GROUNDWATER DISCHARGE TO

THE COLUMBIA RIVER IN THE 100-N AREA

T. J Gilmore

D. R. Newcomer

S. K. Wurstner

F. A. Spane

Apri1 1992

Prepared for

the U.S. Department of Energy

under Contract DE-AC06-76RLO 1830

Pacific Northwest Laboratory

Richland, Washington 99352 


\section{SUMMARY}

A computer code called WATDIS (an acronym for water discharge) was deve1oped that, when used with the commercially available software, WATER-VEL ${ }^{\text {Tw }}$, calculates the volumetric discharge to a specific cross-sectional area of the aquifer. This report describes the development of the WATDIS code and its application. The development of this code is Phase I of a two-phased project whose objective is to estimate the amounts of radionuclides reaching the Columbia River through the unconfined aquifer as a result of "natural" conditions. 


\section{ACKNOWLEDGMENTS}

This technical report was prepared for and sponsored by the Westinghouse Hanford Company, Facility Operations Division. Information about well coordinates was provided by Craig Perkins, Westinghouse Hanford Company. Terry Liikala and Steve Teel contributed to this report. 


\section{CONTENTS}

SUMMARY . . . . . . . . . . . . . . . . . . . . . . .

ACKNOWLEDGEMENTS . . . . . . . . . . . . . . . . . . . . . v v

INTRODUCTION . . . . . . . . . . . . . . . . . . . . . . 1

PROGRAM PARAMETER INPUTS . . . . . . . . . . . . . . . . . 3

HYDRAULIC HEAD DATA . . . . . . . . . . . . . . . . . 3

HYDRAULIC PROPERTY ESTIMATES . . . . . . . . . . . . . . 6

CROSS-SECTIONAL DISCHARGE PLANE . . . . . . . . . . . 6

PROGRAM ASSUMPTIONS . . . . . . . . . . . . . . . . . . . . 9

PROGRAM TEST RUNS . . . . . . . . . . . . . . . . . . . 11

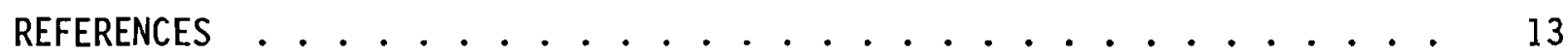

APPENDIX A - WATDIS PROGRAM DESCRIPTION . . . . . . . . . . . A.1

APPENDIX B - AQUIFER TEST ANALYSIS . . . . . . . . . . . . . . B.I

APPENDIX C - PROGRAM TEST RUNS . . . . . . . . . . . . . . . c. 1 


\section{INTRODUCTION}

This report concerns the development of a computer program to calculate the regional flux of groundwater, near the $N$ Reactor on the U.S. Department of Energy- (DOE-) operated Hanford Site in Washington State. This regional flux of groundwater eventually discharges to the Columbia River. This paper reports on the first of two phases of a study that will ultimately provide a procedure and/or computer code to estimate the mass of radionuclides reaching the river through natural groundwater discharge.

Two liquid waste disposal facilities (LWDFs), 1301-N and 1325-N, were used for the disposal of effluents with low-level fission and activation products from the $\mathrm{N}$ Reactor operations. The 1301-N Facility operated from the time of reactor startup in 1963 unt $i 1$ 1985; the 1325-N facility operated from approximately 1985 to November 1989, when the operational status of the $\mathrm{N}$ Reactor was converted to dry layup. In November 1989, the 1325-N LWDF began to receive less than $300 \mathrm{gpm}$ of waste-water, down from the approximately $1500 \mathrm{gpm}$ of waste-water that the facility received during reactor operations. These LWDFs were designed to remove, by sorption, filtration, and ion exchange, a high percentage of radionuclides in the effluent. Much of the low-level fission and activation material from the effluent remains in the sediments. The natural groundwater flow through the area will mobilize some of these products and discharge them to the Columbia River. Westinghouse Hanford Company (Westinghouse Hanford) requested that Pacific Northwest Lab$\operatorname{oratory}^{(a)}(P N L)$ develop a procedure and/or computer program to estimate the amounts of radionuclides reaching the Columbia River through the unconfined aquifer from "natural" regional groundwater flow. To address this problem, a two-phased program was proposed. The first phase, results of which are reported here, includes the development of a computer program for calculating the quantity of groundwater flowing toward the 100-N Area that ultimately discharges to the Columbia River. The second phase will use the results

(a) Pacific Northwest Laboratory is operated for the U.S. Department of Energy by Battelle Memorial Institute, under Contract DE-AC06-76RLO 1830. 
generated by this program for estimating the mass of radionuclides reaching the river through natural groundwater discharge.

The objective of Phase I of this project was to develop a computer program that could be, used to estimate the regional groundwater flow component in the 100-N Area discharging through a given cross-sectional area within the upper unconfined aquifer to the Columbia River under natural hydraulic gradient conditions.

To estimate groundwater discharge, the following information about the aquifer must be known: the hydraulic gradient, the hydraulic properties, and properties of a representative cross section through which the groundwater discharge will be calculated. To facilitate the use of this information for estimating groundwater discharge, a computer program called WATDIS (an acronym for water discharge) was developed. When used with the commercially available computer program WATER-VEL' (In-Situ Inc. 1991), WATDIS calculates the volumetric discharge to a specified cross-sectional area of the aquifer. The two programs are linked by a batch file and are designed to run on an IBM PC or compatible computer system. The WATDIS program is described in Appendix A. 


\section{PROGRAM PARAMETER INPUTS}

An integral part of Phase I was to review current information and determine various inputs for use in the programs. Inputs to WATER-VEL" include potentiometric (head) measurements, effective porosity, and one of three sets of aquifer properties: permeability $(k)$, hydraulic conductivity $(K)$, or transmissivity $(T)$. WATER-VEL ${ }^{\text {M }}$ calculates and outputs the natural groundwater flow rate and the flow direction. The outputs from WATER-VEL ${ }^{m}$ are then used as part of the inputs to the WATDIS program. Additional inputs to the WATDIS program include the coordinates and saturated thickness of the aquifer at two points selected by the user. This section describes the validation process for these inputs for each of the programs.

\section{HYDRAULIC HEAD DATA}

Hydraulic head data are needed to determine the regional hydraulic gradient and flow direction for use in WATER-VEL" A minimum of three hydraulic head inputs are required to define a plane from which a gradient is determined. The program can, however, perform a least-squares fit to a plane with up to 300 hydraulic head inputs. To verify that viable hydraulic head data were available, wells upgradient of the 100-N Area were evaluated based on 1) location upgradient, 2) completion intervals in the upper unconfined aquifer, and 3) hydraulic head fluctuations that reflect natural conditions. Five wells were selected that appear to provide similar representative hydraulic head inputs: 699-71-52, 699-73-61, 699-77-54,699-78-62, and 699-81-58 (Figure 1). For each we11, well completion information was obtained from the Hanford Environmental Information System (HEIS) data base to verify that the wells were completed in the upper unconfined aquifer and that all had similar well construction. Completion intervals of the selected wells range from approximately $15 \mathrm{ft}$ at we11 699-73-61 to $45 \mathrm{ft}$ at we11 699-81-58. Each well was completed at the top of the unconfined aquifer. Geologic information from the HEIS data base indicated that the sediments in the completion zones of these wells were a heterogenous mix, ranging from silt to gravel. There were no apparent confining units or otherwise distinct lithologic layers within any of the completion zones that might affect their hydrologic 


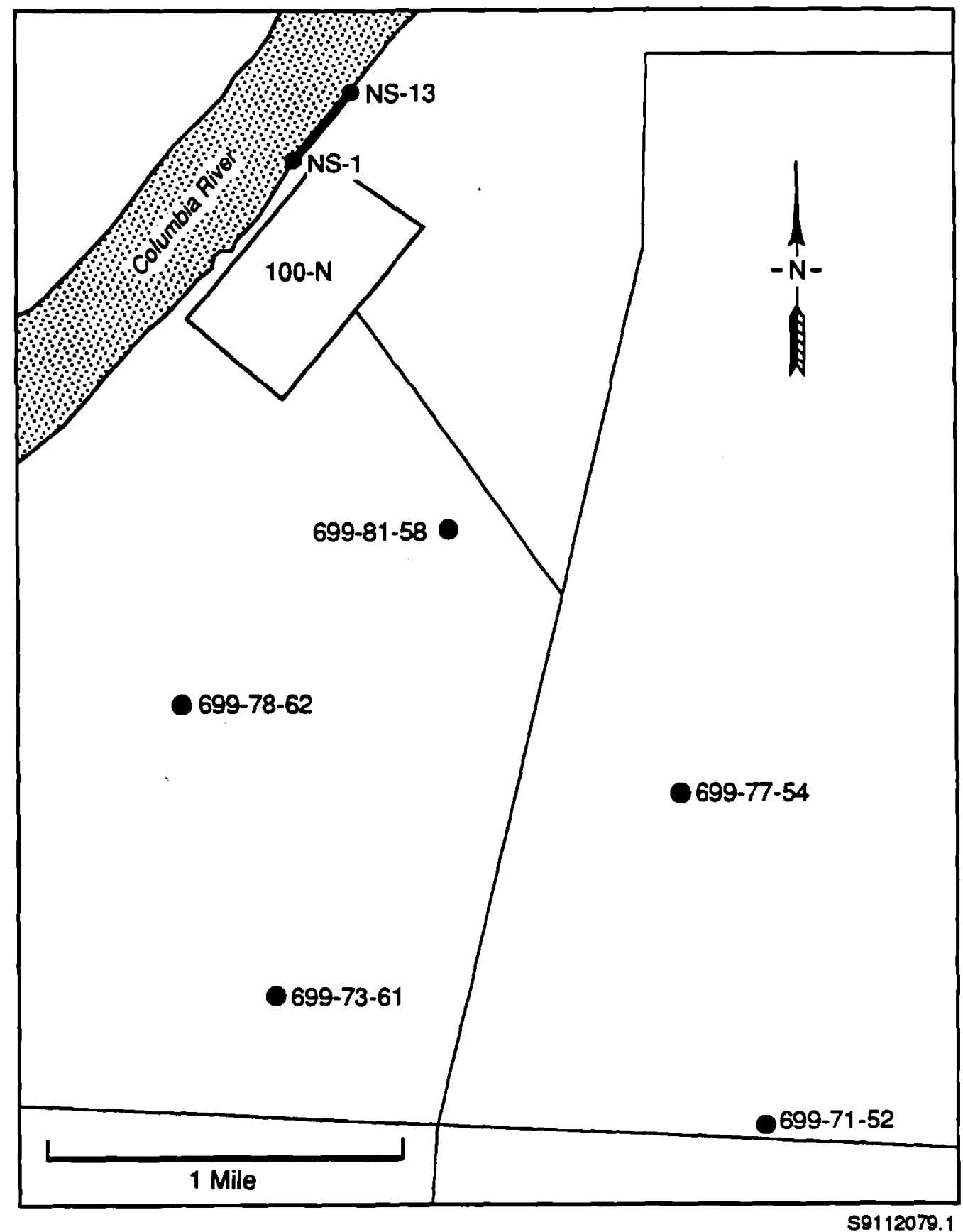

FIGURE 1. Location of Well Network. Bold 1 ine from NS-1 to NS-13 indicates discharge cross section. Note: Well numbering, $699^{(a)}-x x^{(b)}-x x^{(c)}$, is based on Hanford site coordinates.

(a) 600 Area wells.

(b) Thousand feet north of arbitrary Hanford gird line.

(c) Thousand feet west of arbitrary Hanford gird line. 
responses relative to other wells in the area. To verify the similarity in hydrologic responses, data for all five wells from 1987 to 1991 were plotted to evaluate trends in the hydrologic responses (Figure 2). The trends for four of the five wells indicate a slight decline in potentiometric head. Well 699-81-58 displays the most variability of the five wells, exhibiting a larger decline in hydraulic head in the period between December 1989 and June 1991. Well 699-81-58 is the nearest to the 100-N Area, and therefore this decline in potentiometric head is attributed to the November 1989 operational change at the $\mathrm{N}$ Reactor to dry layup status. This operational change resulted in a dramatic decrease in waste-water discharged to the ground. Although this situation violates the third criterion for well selection (hydraulic head fluctuations must reflect natural conditions), Gilmore et al. (1991) suggest this well has nearly reached a new equilibrium with the water table and the

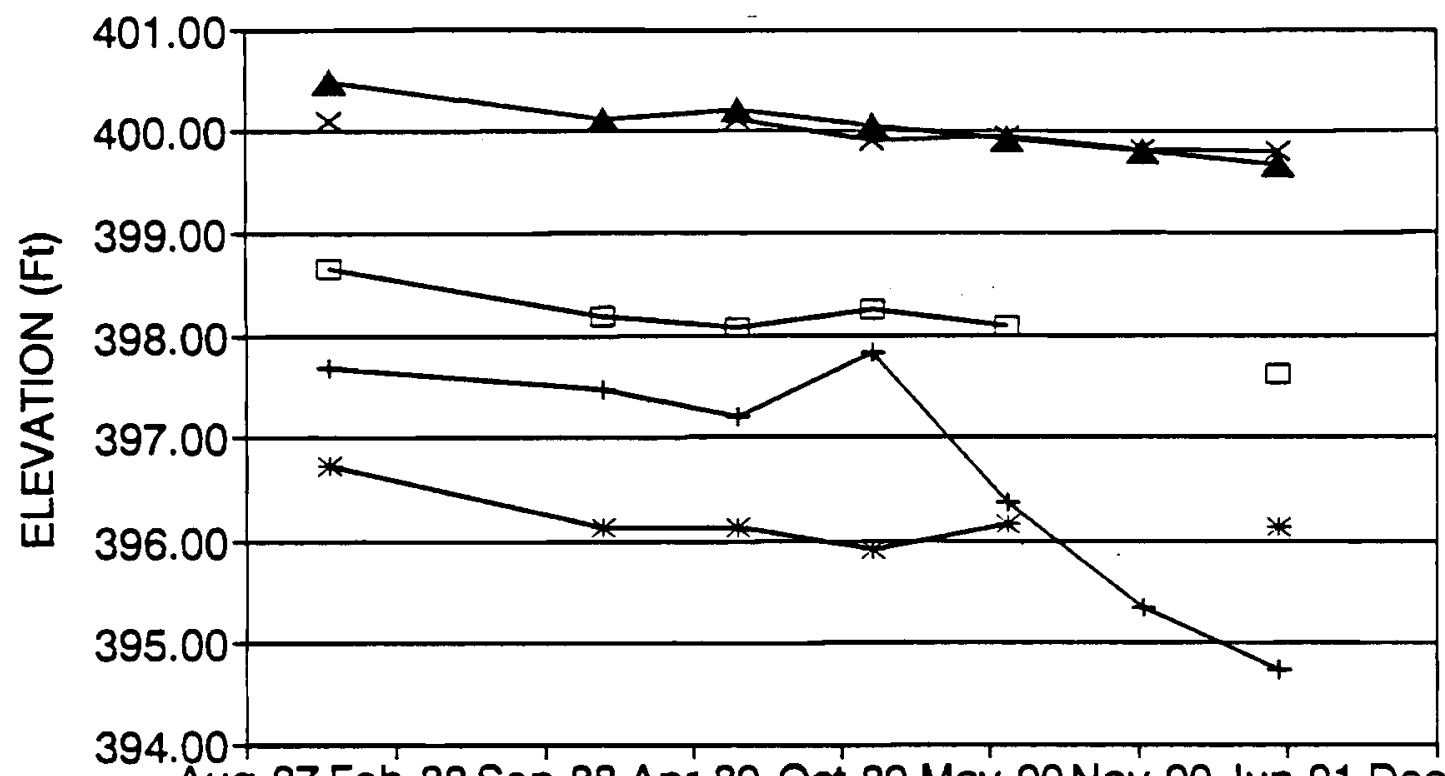

Aug-87 Feb-88 Sep-88 Apr-89 Oct-89 May-90 Nov-90 Jun-91 Dec-91 DATE

$$
\begin{aligned}
& \longrightarrow \text { Well 699-81-58 } \rightarrow \text { Well 699-78-62 } \because \text { Well 699-77-54 } \\
& \leftarrow \text { Well 699-73-61 } \leftarrow \text { Well 699-71-52 }
\end{aligned}
$$

FIGURE 2. Hydrographs of Program Input Wells 
effects of artificial groundwater recharge from the 100-N Area have decreased significantly. Data from all five wells are recommended for use with the computer code. Conditions in all five wells selected to provide input are measured for hydraulic head annually as part of PNL's Hanford Site-wide groundwater monitoring program, and results of chemical and radiological analyses are available in the Hanford Groundwater Data Base.

\section{HYDRAULIC PROPERTY ESTIMATES}

To determine groundwater velocity, WATER-VEL ${ }^{\mathbb{M}}$ requires estimates of the aquifer's hydraulic properties (e.g., effective porosity, $k, K$, and $T$ ). The effective porosity for the Ringold Formation, 0.11, was taken from DOE (1988).

Hydraulic conductivity ( $K$ ) is the parameter used in this study. Hydraulic property information is available from aquifer tests conducted in two wells within the study area. Hydraulic conductivity values are available from aquifer tests on 699-77-54, one of five monitoring network wells, and from wel1 699-87-55, which is to the northeast of the well network. Previously published results for hydraulic conductivity ranged from 69 to $770 \mathrm{ft}$ per day (Kipp and Mudd 1973; Deju 1974; Bierschenk 1959). Because of the wide range in reported hydraulic property estimates, the original aquifer test data, from 1957 and 1969, were reanalyzed for this project. The reanalyzed data yielded hydraulic conductivity estimates of 48 to $55 \mathrm{ft}$ per day. The results of the reanalysis are discussed in Appendix $B$.

\section{CROSS-SECTIONAL DISCHARGE PLANE}

To calculate the discharge through a specified cross section using WATDIS, the coordinates of the cross-sectional end-points and the saturated thickness of the unconfined aquifer at each end-point are required. The endpoints specify the plane through which the groundwater discharge is to be calculated. A section along the Columbia River shoreline where the $N$ Springs are known to discharge was selected for use as the cross section in the example calculation of groundwater discharge. The cross-sectional area was defined by the coordinates of N Springs wells NS-1 and NS-13. The coordinates and saturated thickness at each location are listed in Table 1. The saturated 
TABLE 1. Cross-Sectional Endpoint Coordinates for Example Groundwater Discharge Calculations

\begin{tabular}{|c|c|c|c|}
\hline & \multicolumn{2}{|c|}{ Coordinates, $\mathrm{ft}$} & Saturated \\
\hline Location & $E_{0}$ & $\mathrm{~N}_{p-}$ & Thickness, ft \\
\hline $\begin{array}{l}\text { NS }-1 \\
N S-13\end{array}$ & $\begin{array}{l}-61129 \\
-60266\end{array}$ & $\begin{array}{l}86674 \\
87865^{\star}\end{array}$ & $\begin{array}{l}50 \\
50\end{array}$ \\
\hline
\end{tabular}

All coordinates in Hanford Plant coordinate system. * designates wells surveyed by Kaiser Engineers Hanford. Other coordinates taken from maps of the 100-N Area.

thickness of the aquifer at these points was calculated from 1 ithologic diagrams from wells 199-N8T, 199-N-69, and 199-N-5. These wells all penetrated a clay layer at approximately $351 \mathrm{ft} \mathrm{M.S.L.} \mathrm{This} \mathrm{clay} \mathrm{layer} \mathrm{is} \mathrm{generally} \mathrm{con-}$ sidered the bottom of the unconfined aquifer in the area (Gilmore et al. 1991; Connelly et a1. 1991). The elevation of the ground surface near the river was taken from the surveyed elevation of $\mathrm{N}$ Springs well NS-2, yielding a saturated thickness of approximately $50 \mathrm{ft}$.

Any two points downgradient of the well network with their respective saturated thickness may be used for input into this computer code. However, the user is cautioned that the nearer the river the points are, the larger the uncertainty of the groundwater flux calculations becomes, because of bank storage and vertical gradients near the river. 


\section{PROGRAM ASSUMPTIONS}

The WATER-VELM/WATDIS program determines groundwater flow direction and velocity by fitting a linear, two-dimensional trend surface (least squares) to randomly located hydraulic head data. This technique is accurate as long as the two-dimensional, linear approximation is applicable, i.e., as long as no significant vertical groundwater flow gradients exist, and the piezometric surface does not have major perturbations.

This program provides a qualitative steady-state estimate of the regional groundwater flux and assumes that the water calculated to flow through a specified plane discharges directly to the Columbia River. It does not take into account temporal variations in river stage, which may delay or deflect groundwater estimated to be flowing through the plane. To evaluate site-specific discharges to the Columbia River, a more detailed model that takes into account bank storage and other factors would have to be developed. However, the WATDIS program could provide regional flux input for the more detailed model.

The program assumes the unconfined aquifer is homogeneous and isotropic and that there is no net pumping or recharge to the aquifer. This assumption is not met; however, the net effects of aquifer variability may approximate these conditions when a large enough area is considered. 


\section{PROGRAM TEST RUNS}

To determine the program's sensitivity to the variability in the input parameters, several test runs were conducted using water-level data from December 1987 and 1989 and June 1989, 1990, and 1991. (These collection periods contained water-level data for all five wells in the network.) To evaluate the respective influence of each input parameter, the hydraulic conductivity and the number of wells in the network were varied. The results of the parameter sensitivity analysis are presented in Appendix C.

The hydraulic conductivity value was input as 40,50 and $60 \mathrm{ft} / \mathrm{d}$. The recommended value based on aquifer test evaluations is $50 \mathrm{ft} / \mathrm{d}$. Varying hydraulic conductivity directly affects groundwater velocity, which in turn affects the calculated discharge volumes. The discharge calculations vary by approximately $215 \mathrm{ft}^{3} / \mathrm{d}$ (or $20 \%$ variance) in calculated discharge to the designated cross section with every $10 \mathrm{ft} / \mathrm{d}$ change in hydraulic conductivity.

The sensitivity of the computer code was also tested by varying the network of wells used for hydraulic head input. Varying the wells in the network directly affects the hydraulic head gradient and the resultant calculated groundwater flow direction and velocity. Five wells were originally chosen for the network based on criteria discussed above. Three of the wells for hydraulic head input (699-78-62, 699-81-58 and 699-71-52) were used to test the computer code's sensitivity to the well network configuration. The hydraulic head data from each of these wells were deleted from the input file one at a time, leaving input from four wells for each run (Appendix C). When the westernmost we11, 699-78-62, was deleted from the network, the calculated discharge to the designated cross-sectional area decreased. The amount of decrease is dependent on the date of the hydraulic head input. Using the most recent data (June 1991), the discharge volume decreased approximately $240 \mathrm{ft}^{3} /$ day. When the southernmost we11, 699-71-52, was deleted from the network, the calculated discharge increased approximately $537 \mathrm{ft}^{3} /$ day, representing a 45\% increase in the calculated discharge (June 1991 data). When well 699-81-58 was deleted from the network, there was not a significant difference in the calculated discharge using the June 1991 data. When older data are 
used, particularly data from the years when there was significant artificial recharge in the 100-N Area, the deletion of well 699-81-58 increased the calculated discharge. This is believed to be the result of the elevated groundwater levels under the 100-N Area prior to November 1989. Well 699-81-58 was under the influence of this artificially elevated groundwater table (Gilmore et a1. 1991), and when this well is deleted from the input file, the calculated gradient toward the $100-\mathrm{N}$ Area increases, resulting in an increase in calculated discharge volumes.

It is recommended that data from all five wells be used in the computer code. Altering the well network can substantially affect the amount of groundwater discharge that is calculated. 


\section{REFERENCES}

Bierschenk, W. H. 1959. Aquifer Characteristics and Ground-Water Movement. HW-60601, General Electric Hanford Atomic Products Operation, Richland, Washington.

Connelly, M. P., J. D. Davis, and P. D. Rittmann. 1991. Numerical Simulation of Strontium-90 Transport from the 100-N Area Liquid Waste Disposal Facilities. WHC-SD-ER-TA-001, Rev. 0, Westinghouse Hanford Company, Richland, Washington.

Deju, R. A. 1974. The Hanford Field Testing Program. Report prepared for Atlantic Richfield Hanford Company, Richland, Washington.

DOE. 1988. Consultation Draft: Site Characterization Plan, Reference Repository Location, Hanford Site, Washington. DOE/RW-0164, U.S. Department of Energy, Washington D.C.

Gilmore, T. J, J. V. Borghese, and D. R. Newcomer. 1991. Evaluations of the Effects of the Columbia River on the Unconfined Aquifer Beneath the $100-\mathrm{N}$ Area. PNL-7646, Pacific Northwest Laboratory, Richland, Washington.

In-Situ Inc. 1991. WATER-VEL Groundwater Velocity. ISI-GWV-2.21-1, In-Situ Inc., Laramie, Wyoming.

Kipp, K. L., and R. D. Mudd. 1973. Collection and Analysis of Pump Test Data for Transmissivity Values. BNWL-1709, Batte1le, Pacific Northwest Laboratories, Richland, Washington. 
APPENDIX A

WATDIS PROGRAM DESCRIPTION 
APPENDIX A

\section{WATDIS PROGRAM DESCRIPTION}

\section{A.1 INTRODUCTION}

\section{A.1.1 Purpose}

The purpose of the program WATDIS is to calculate the groundwater discharge across a specified cross-sectional plane in an aquifer. The program uses the groundwater velocity and direction calculated by the program WATERVEL ${ }^{\text {TM }}$ (In-Situ Inc. 1991).

\section{A.1.2 Hardware Requirements}

WATDIS requires an IBM PC or IBM-compatible computer system with MS DOS version 3.3 or higher. A math co-processor is not necessary. The program can be run separately or in combination with WATER-VELM.

\section{A.2 PROGRAM WATDIS}

\section{A.2.1 Program Description}

WATDIS is a FORTRAN program that calculates groundwater discharge. It uses an output file from the program WATER-VEL ${ }^{M}$ along with user inputs to calculate the groundwater discharge to a defined area of an aquifer. The WATER-VEL"M output file provides WATDIS with the title of the run, the effective porosity of the aquifer, the groundwater velocity, and the groundwater flow angle in degrees from the positive $x$-axis of the coordinate system used in the calculation. The user must provide WATDIS with information that describes the cross-sectional plane across which the discharge calculation is made. Figure A.l shows a flow chart describing the operation of the WATDIS program.

The groundwater discharge, or volumetric flux, can be calculated using the following equation (Freeze and Cherry 1979):

$$
Q=q_{n} \cdot A
$$

\section{A. 1}




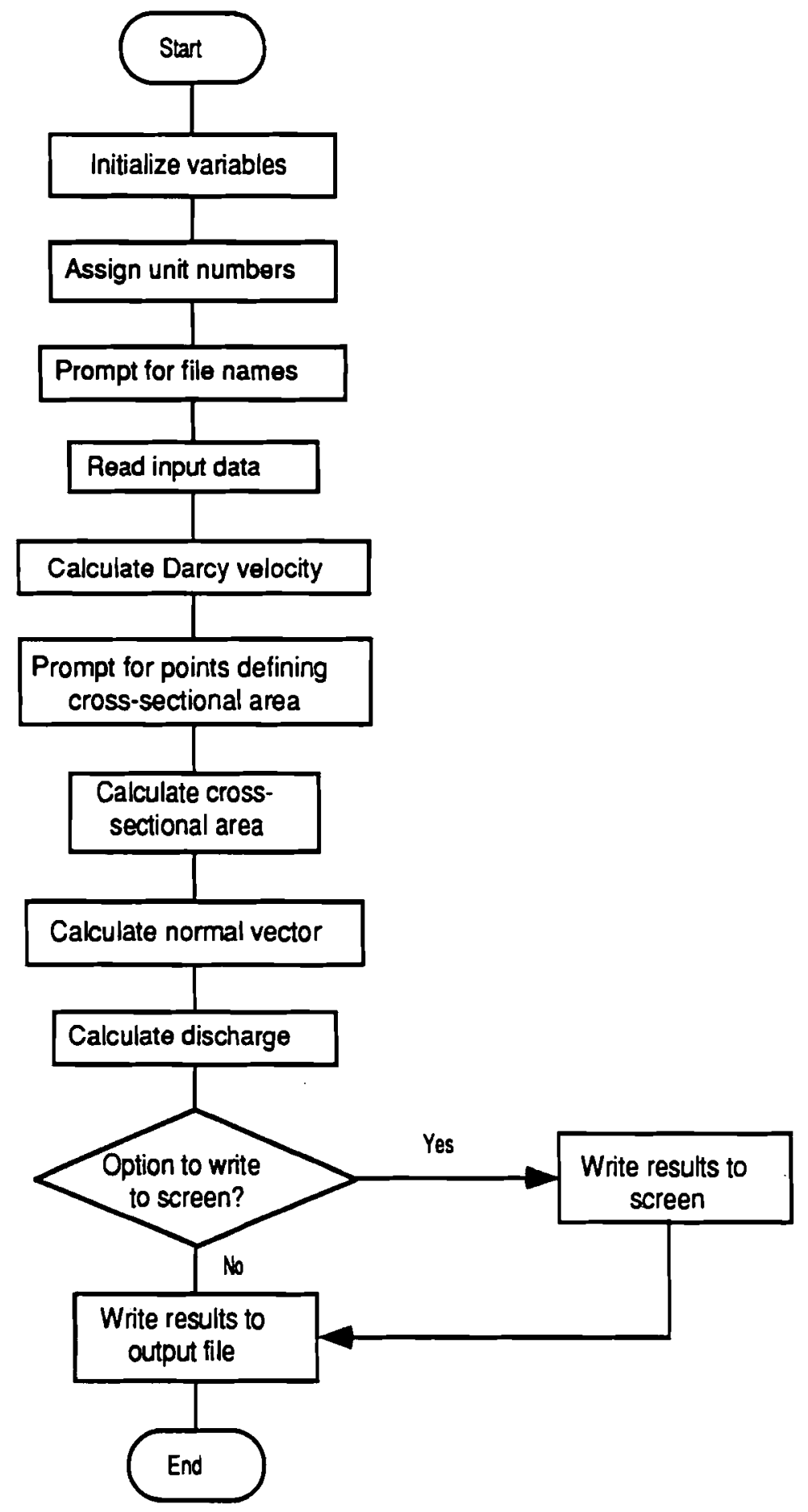

FIGURE A.1. Flow Chart for WATDIS

A. 2 
where $Q=$ groundwater discharge $\left(L^{3} / t\right)$

$q_{n}=$ Darcian velocity normal to the cross-sectional area $(L / t)$

$A=$ the saturated cross-sectional area $\left(L^{2}\right)$.

The output from WATER-VEL'M provides the groundwater (or solute) velocity. However, as shown in Equation A.1, the Darcian velocity is needed for the discharge calculation. Therefore, to calculate the groundwater discharge, WATDIS must first calculate the Darcian velocity, defined as

$$
q=v_{s} \cdot \phi
$$

$$
\text { where } \begin{aligned}
q & =\text { Darcian velocity }(L / t) \\
v_{s} & =\text { groundwater or solute velocity }(L / t) \\
\phi & =\text { effective porosity of the aquifer. }
\end{aligned}
$$

The user must specify the cross-sectional plane across which the discharge calculation is made. This plane is defined by a trapezoid (Figure A.2), where side a is the saturated thickness (vertical dimension) at point 1 , side $b$ is the saturated thickness (vertical dimension) at point 2, and $w$ is the horizontal distance between the two points. Therefore, the necessary inputs to define the trapezoid are the coordinates of two points and the saturated thickness at each point.

The area of the designated cross section is calculated using the trapezoid area relationship as follows:

$$
A=\frac{1}{2}(a+b) w
$$

where $A=$ the area of the trapezoidal cross-section $\left(L^{2}\right)$

$a=$ the saturated thickness at point $1(L)$

$b=$ the saturated thickness at point 2 (L)

$w=$ the horizontal distance between the two points $(L)$.

Although the Darcian velocity can be easily calculated from the WATER$V L^{\text {TM }}$ information, the calculated flow direction may not be perpendicular to the cross-sectional plane that is specified by the user. To calculate the 
volumetric flux entering the designated cross-sectional area, the component of the Darcian velocity that is perpendicular (or normal) to the cross-sectional plane must be determined. This can be done using the dot product of two vectors (Anton 1984), where

$$
\vec{v}_{n}=\vec{v} \cdot \hat{n}
$$

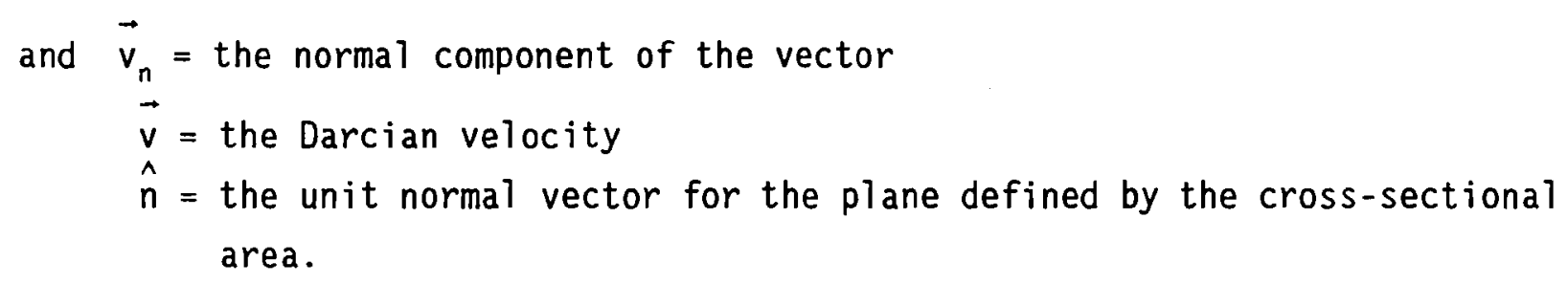

The groundwater discharge can then be determined using Equation A.1.

\section{A.2.2 Program Assumptions}

WATDIS assumes that the user's units and coordinate system are consistent with the WATER-VEL' ${ }^{\text {M }}$ output file that is used as program input. WATERVEL'M assumes that the aquifer is homogeneous, that the water-level data for the selected wells represent equilibrated steady-state conditions within the aquifer system, and that there is no active pumping or groundwater disposal in the study area. Since WATDIS calculates discharge from the velocity that is output by WATER-VEL" , these assumptions about the aquifer extend to the WATDIS program.

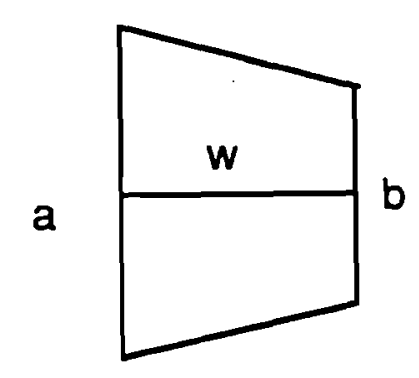

FIGURE A.2. Trapezoid 


\section{A.3 INPUT}

WATDIS is an interactive program that prompts the user for several inputs. These inputs are

Input filename - The name of the input file. This file must be in the format of a WATER-VEL' output file.

Output filename - The desired name of the output file from WATDIS.

The remaining inputs are prompted for by a menu. The user is given a list of information needed to run the program and may then choose which parameter to input and is prompted for its value. The required inputs in the menu are as follows:

Coordinates for two points - The $x$ and $y$ coordinates for the two points that will describe the cross-sectional plane across which the discharge calculation is to be made. This report is using the Hanford Site Coordinates. These coordinates can be from any coordinate system, provided that they are consistent with the coordinate system used in WATER-VEL'm.

Saturated thickness at each point - The saturated thickness (or aquifer thickness) at the locations of the two points that define the cross-sectional plane.

Option to print output to screen - If the option is activated (by answering 'yes'), output will be displayed on the screen as well as written to an output file. Otherwise, the output is printed only to the designated output file. The default is to print to the output file only.

Note that the units for all inputs can be either English or metric, provided that they are consistent with those found in the input file (i.e., a WATER-VEL ${ }^{\text {NM }}$ output file).

\section{A.3.1 Example Menu}

The following is an example of a WATDIS menu:

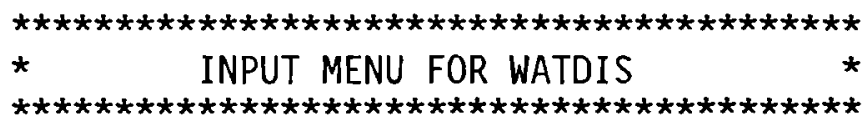

1.TITLE: test run 1
2.COORDINATES OF POINT 1
$E W=-55405.00$
$\mathrm{NS}=86707.00$ 


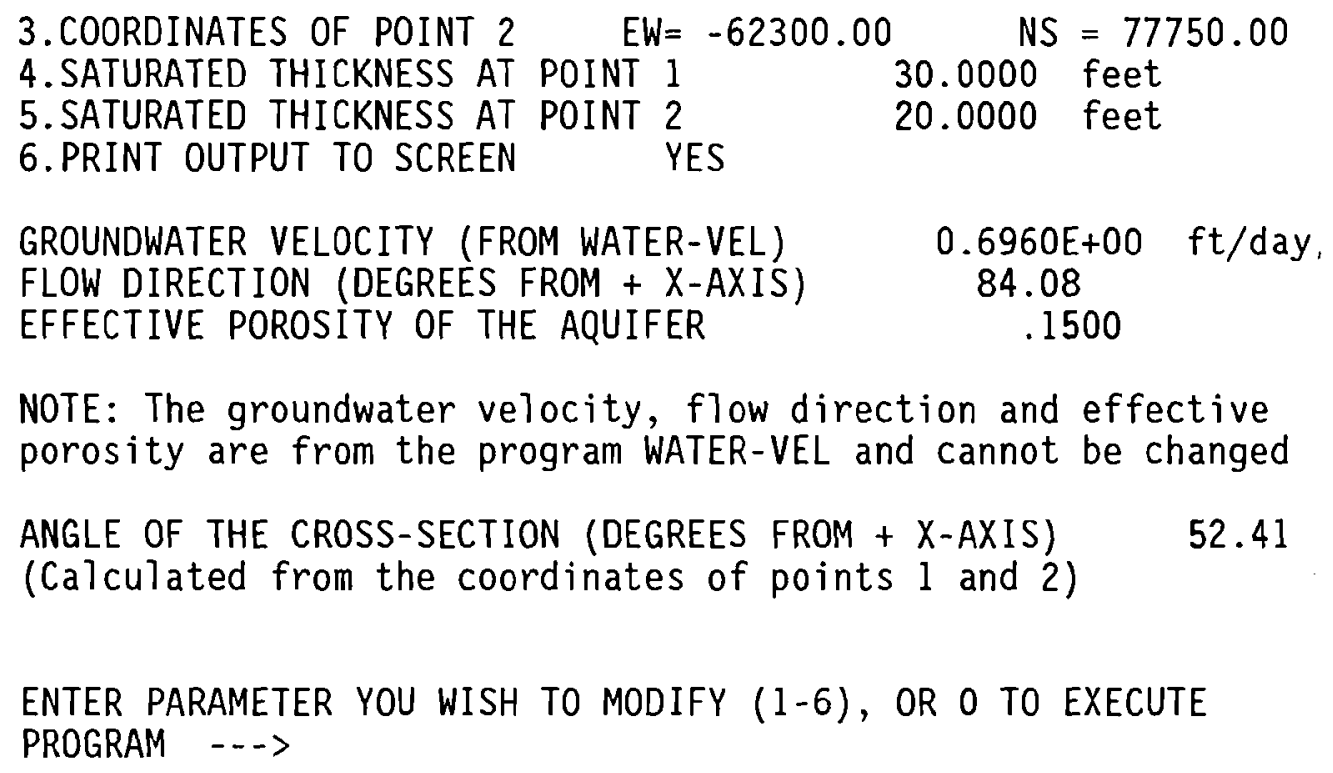

\section{A.3.2 Menu Data File}

WATDIS creates a file called 'watmenu.dat' that stores the input data from the previous run (the coordinates of the two points, the saturated thickness at each point, the option to print output to the screen, and the angle of the cross-sectional plane). This file is created as a convenience to the user. It allows the user to run WATDIS with different input files but the same cross-sectional area without having to enter the defining data points each time. The program will run if watmenu.dat is not present in the same directory, but the menu will contain zeros for the data values and the user will have to enter a 11 inputs. WATDIS will create the watmenu.dat file if it does not exist, or update the existing watmenu.dat file during each run.

\section{A. 4 OUTPUT}

The output file from WATDIS provides a record of the input information, the Darcian velocity, the normal component of the Darcian velocity, the area of the saturated cross section, the angle of the cross section measured in degrees from the positive $x$-axis, and the groundwater discharge to that area. 
The angle of the cross-sectional $\mathrm{pl}$ ane to the $\mathrm{x}$-axis is provided as a check for the user. The calculation is done by extending the plane to the point where it crosses the positive $x$-axis, and then measuring the angle from that axis intersection.

\section{A.4.1 Example Output}

The following is an example of output from WATDIS:

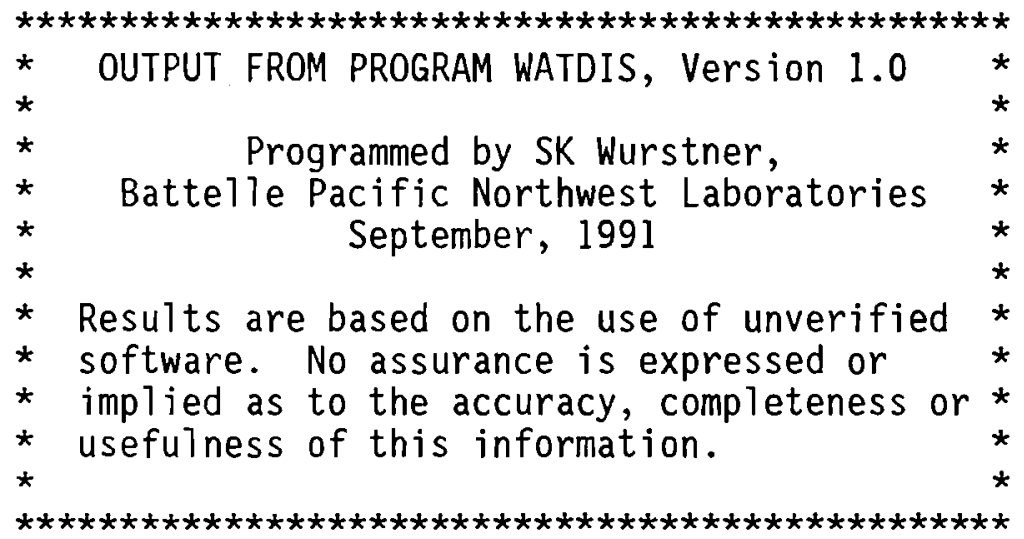

ECHO OF INPUT

INPUT FILENAME： 0689WL.OUT

OUTPUT FILENAME: AQFL.OUT

\begin{tabular}{|c|c|}
\hline 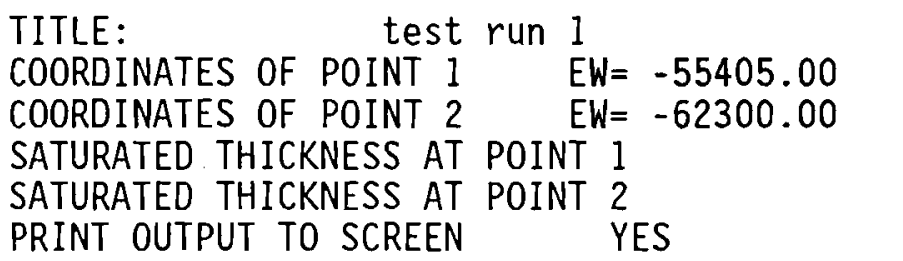 & $\begin{array}{c}\text { NS }=86707.00 \\
N S=77750.00 \\
30.0000 \text { feet } \\
20.0000 \text { feet }\end{array}$ \\
\hline $\begin{array}{l}\text { GROUNDWATER VELOCITY (FROM WATER-VEL) } \\
\text { FLOW DIRECTION (DEGREES FROM + X-AXIS) } \\
\text { EFFECTIVE POROSITY OF THE AQUIFER }\end{array}$ & $\begin{array}{l}0.6960 \mathrm{E}+00 \mathrm{ft} / \mathrm{day} \\
84.08 \\
.1500\end{array}$ \\
\hline CALCULATED VALUES & \\
\hline $\begin{array}{l}\text { DARCIAN VELOCITY (ANGLE OF } 84.08 \text { DEGREES) } \\
\text { NORMAL COMPONENT OF THE DARCIAN VELOCITY) }\end{array}$ & $\begin{array}{ll}0.1044 \mathrm{E}+00 & \mathrm{ft} / \mathrm{day} \\
0.5481 \mathrm{E}-01 & \mathrm{ft} / \mathrm{day}\end{array}$ \\
\hline
\end{tabular}




$$
\begin{aligned}
& \text { AREA OF THE SATURATED CROSS-SECTION } \\
& \text { ANGLE OF THE CROSS-SECTION (DEGREES FROM + X-AXIS) } 0.282587 \mathrm{E}+06 \mathrm{ft}^{\wedge} 2 \\
& \text { GROUNDWATER DISCHARGE ACROSS THE AREA } 0.154888 \mathrm{E}+05 \mathrm{ft} \mathrm{ft}^{\wedge} / \mathrm{day}
\end{aligned}
$$

\section{A.5 REFERENCES}

Anton, H. 1984. Calculus with Analytic Geometry, 2nd Edition. John Wiley and Sons, New York.

Freeze, R. A., and J. A. Cherry. 1979. Groundwater. Prentice-Ha11, Englewood Cliffs, New Jersey.

In-Situ Inc. 1991. WATER-VEL" Groundwater Velocity. ISI-GWV-2.21-1, In-Situ Inc., Laramie, Wyoming. 
APPENDIX B

AQUIFER TEST ANALYSIS 
APPENDIX B

\section{AQUIFER TEST ANALYSIS}

Hydraulic property estimates for the unconfined aquifer in the vicinity of the 100-N Area have been reported by Bierschenk (1959), Kipp and Mudd (1973), and Deju (1974). These estimates are based on aquifer tests conducted for wells 699-77-54 and 699-87-55. Hydraulic conductivity estimates obtained from these test analyses vary by over a factor of ten, ranging from 69 to $770 \mathrm{ft}$ per day. A review of the original test data and previous test analyses identified two principal reasons for the wide range in reported hydraulic conductivity values: misapplication of analytical test methods and inappropriate application of straight-line analyses for non-radial flow test data periods.

Hydraulic conductivity estimates provided by Kipp and Mudd (1973) for we11 699-77-54 are based on log-log, type-curve analysis of pumping test drawdown and recovery data. The $\log -\log$, type-curve matching method, however, is only strictly correct for analys is of observation-well test response (i.e., in multiple-well interference tests). Quantitative log-log analysis of the test response at the pumping well is not completely valid, because several factors contribute to drawdown and recovery that are not normaliy accounted for in the analytical procedure. These nonformational response phenomena, which affect water-level response at the pumping well, include wellbore storage, formation damage or stimulation due to drilling/well construction practices, and pumping variations (Weeks 1978; Earlougher 1977). Misapplication of the analysis method by Kipp and Mudd (1973) for results of pumping tests for wel1 699-77-54 was also noted by Deju (1974).

Another cause of the wide range in reported hydraulic conductivity values is the inappropriate application of straight-line analysis. The use of the Cooper and Jacob (1946) straight-line analysis for pumping test data is 
strictly valid only for test data exhibiting radial flow conditions and for test times that satisfy the prescribed time $(t)$ criterion specified in the relationship

$$
t \geq\left(r^{2} S\right) /(4 T u)
$$

where $r^{2}=$ effective well radius (for pumping well analysis)

$S=$ storativity

$T=$ transmissivity

$u=$ dimensionless parameter equal to 0.01 .

In the analyses presented by Bierschenk (1959) and Deju (1974), a number of misapplications of the straight-line analysis method were identified.

Recent developments in log-log diagnostic analysis have greatly facilitated the identification of the test data sections that can be analyzed using straight-line analysis methods. These recently developed diagnostic methods rely on converting pumping drawdown and recovery pressure data to derivative form and analyzing the shape of the pressure derivative versus time on a loglog diagnostic plot. As noted by others (Bourdet and Alagoa 1984; Clark and Golf-Racht 1985), pressure derivative diagnostic plots can be used to precisely identify regions within the pumping test data set that are controlled by formational (e.g., homogeneous vs. heterogeneous formation response, radial flow conditions) and nonformational factors (e.g., wellbore storage, skin effects).

Pressure derivative analysis was used in the reanalysis of the available pumping test data to identify when radial flow conditions were established during each test. Straight-line analysis methods (e.g., Cooper and Jacob 1946) were then used to analyze the identified radial flow portions of the test. Results and test plots used in the reanalys is are presented below for each well site. 
We11 $699-77-54$

Pumping test data are available for two tests conducted for well 699-77-54. The first test was conducted on July 23, 1957, at an average discharge rate of approximately $194 \mathrm{gpm}$. The test was terminated after a shor.t pumping period of onty 108 minutes. Bierschenk (1959) reported a transmissivity value based on this test analysis of $42,513 \mathrm{ft}^{2} / \mathrm{d}$ and a hydraulic conductivity (based on an aquifer test section of $65 \mathrm{ft}$ ) of $655 \mathrm{ft} / \mathrm{d}$. Based only on analysis of the pumping recovery data, Kipp and Mudd (1973) reported a transmissivity value of $50,000 \mathrm{ft}^{2} / \mathrm{d}$.

Re-examination of the original test data indicates that, because of the extremely short duration of the pumping test (i.e., less than 2 hours), the pumping test drawdown and recovery data were influenced primarily by the "delayed-yield" phenomenon exhibited by unconfined aquifers, and that true radial flow conditions had not been established during the test. Because radial flow conditions were not established before the test was terminated, misapplication of straight-line analysis methods for the test data examined would be expected to overestimate the aquifer's hydraulic properties. Because of these test deficiencies, test data for the first pumping test were not reanalyzed or used in the report for estimating hydraulic properties.

The second test was conducted on September 25, 1969, at an average discharge rate of $147 \mathrm{gpm}$. The test was terminated after a pumping period of 980 minutes. Kipp and Mudd (1973) reported transmissivity estimates for the drawdown and recovery phases of $5,100 \mathrm{ft}^{2} / \mathrm{d}$ and $13,000 \mathrm{ft}^{2} / \mathrm{d}$, respectively. In analyzing the same test data, Deju (1974) reported transmissivity values of $7,400 \mathrm{ft}^{2} / \mathrm{d}$ and $6,500 \mathrm{ft}^{2} / \mathrm{d}$ for these test phases.

In our reanalysis, pumping test drawdown and recovery data were corrected for a saturated thickness reduction, using the following correction method originally presented by Jacob (1963):

$$
s^{\prime}=s-\left(s^{2} / 2 b\right)
$$


where $s^{\prime}=$ corrected drawdown or residual drawdown

$s=$ observed drawdown or residual drawdown

$b=$ aquifer thickness.

Log-log diagnostic analysis of the pressure change and the derivative of pressure with respect to time, as shown in Figures B.1 and B.2, indicates that radial flow conditions were only established in later test times during the drawdown phase and were not actually attained during the measured recovery test period. Results of straight-line analysis for the radial flow portion of the drawdown test data are shown in Figure B.3. As indicated in the figure, a transmissivity value of $3,460 \mathrm{ft}^{2} / \mathrm{d}$ was obtained from the late-time data analysis. This represents the best estimate of transmissivity for the unconfined aquifer in the vicinity of well 699-77-54. A best-estimate value of $48 \mathrm{ft} / \mathrm{d}$ for equivalent hydraulic conductivity was also obtained from this test analysis, based on the best-estimate value for transmissivity and an assigned aquifer thickness of $72 \mathrm{ft}$.

\section{We 11 699-87-55}

Pumping test data are available for one test conducted for wel1 699-87-55. The test was conducted on July 2 and July 3, 1969, at an average discharge rate of approximately $105 \mathrm{gpm}$. The test was terminated after a pumping period of 1170 minutes. Deju (1974) has reported that an average transmissivity value of $4,500 \mathrm{ft}^{2} / \mathrm{d}$ was obtained in analyzing both drawdown and recovery test phases.

As was done in the we11 699-77-54 reanalysis, pumping test drawdown and recovery data were corrected for a saturated thickness reduction, using the correction method of Jacob (1963). Log-log diagnostic analys is of the pressure change and the derivative of pressure with respect to time, as shown in Figures B.4 and B.5, indicates that radial flow conditions were established only in later test times during the drawdown phase and were not attained during the measured recovery test period. Results of straight-line analysis for the radial flow portion of the drawdown test data are shown in Figure B. 6 . As indicated in the figure, a transmissivity value of $1,950 \mathrm{ft}^{2} / \mathrm{d}$ was obtained 


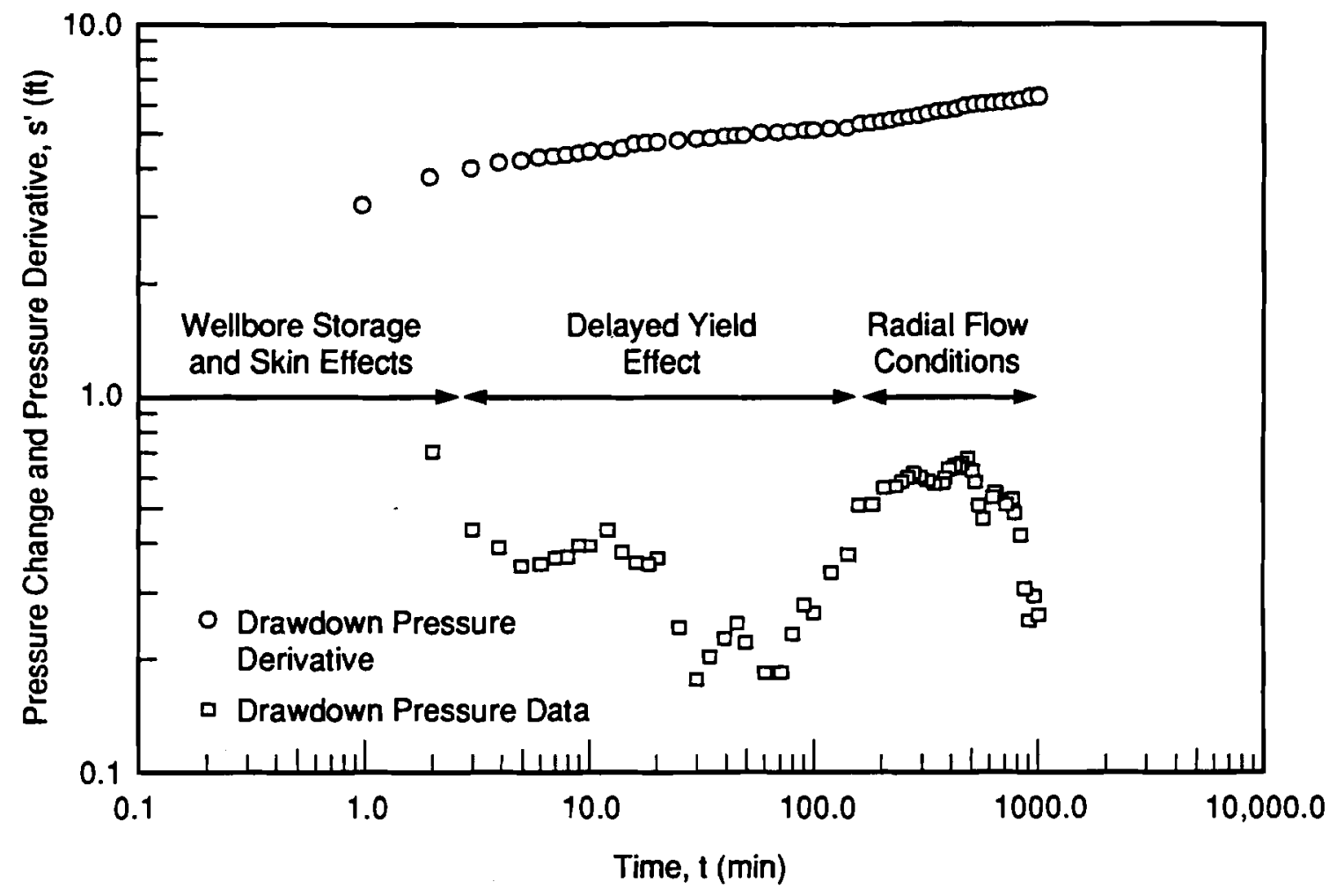

S9201014.1

FIGURE B.1. Drawdown in We17 699-77-54

from the late-time data analysis. This represents the best estimate of transmissivity for the unconfined aquifer in the vicinity of well 699-87-55. A best-estimate value of $55 \mathrm{ft} / \mathrm{d}$ for equivalent hydraulic conductivity was also obtained from this test analysis, based on the best-estimate value for transmissivity and an assigned aquifer thickness of $35 \mathrm{ft}$.

\section{Summary}

A wide range in hydraulic properties has previously been reported for the unconfined aquifer, based on pumping test analyses conducted for wells 699-77-54 and 699-87-55 (Bierschenk 1959; Kipp and Mudd 1973; Deju 1974). Re-examination of the original test data and analyses indicated that many of the early pumping test analyses were in error. Reanalysis of the pumping test data using $\log -\log$ diagnostic analysis and semi-log straight-line analytical 
methods indicated considerably less range in the calculated values for hydraulic properties between the two well sites. Best-estimate values for transmissivity and equivalent hydraulic conductivity based on the reanalysis range from 1,950 to $3,460 \mathrm{ft}^{2} /$ day and from 48 to $55 \mathrm{ft} / \mathrm{d}$, respectively. These estimates are the best values available for the unconfined aquifer within the middle Ringold Formation in this part of the Hanford Site.

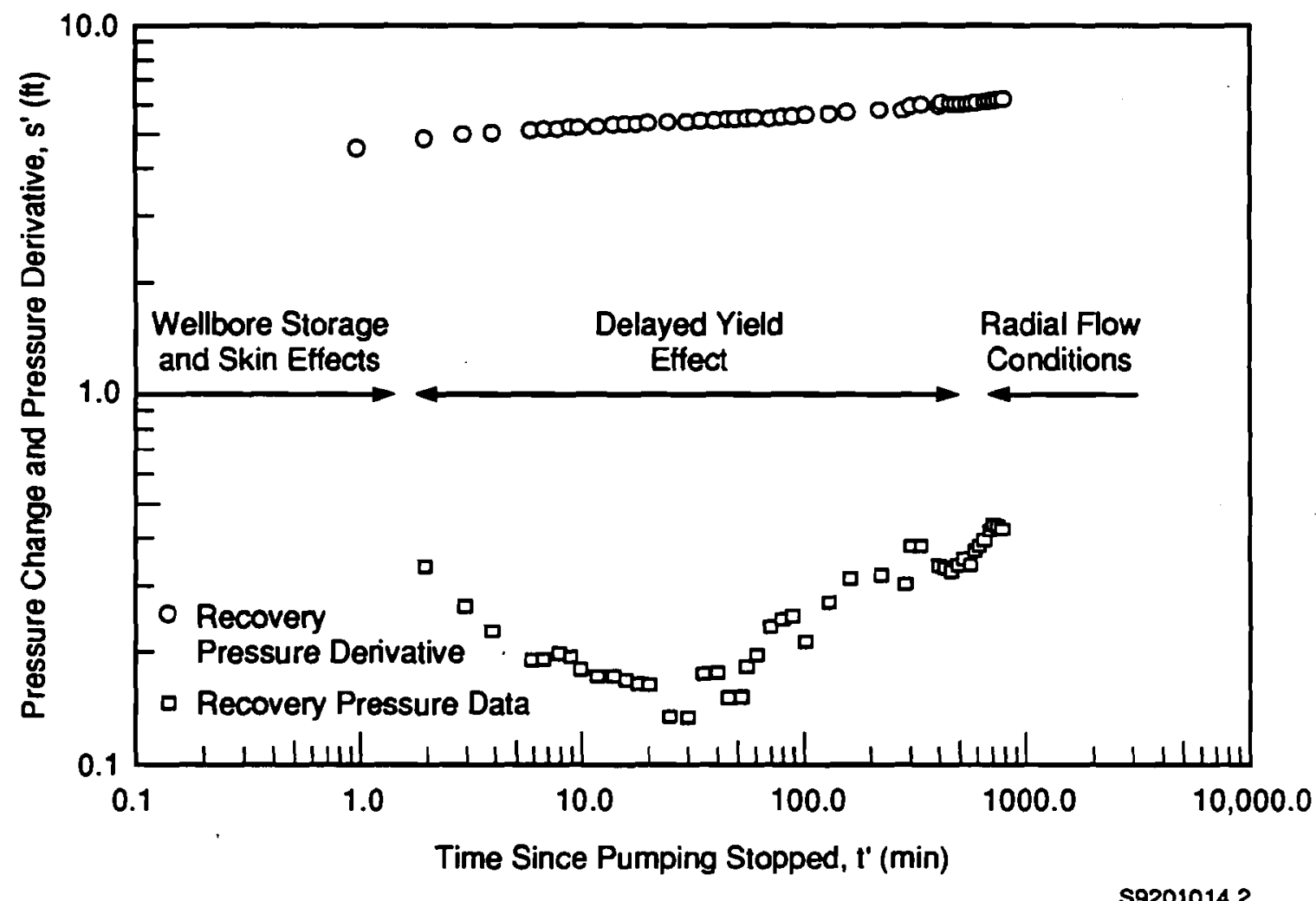

FIGURE B.2. Recovery for Well 699-77-54

B. 6 


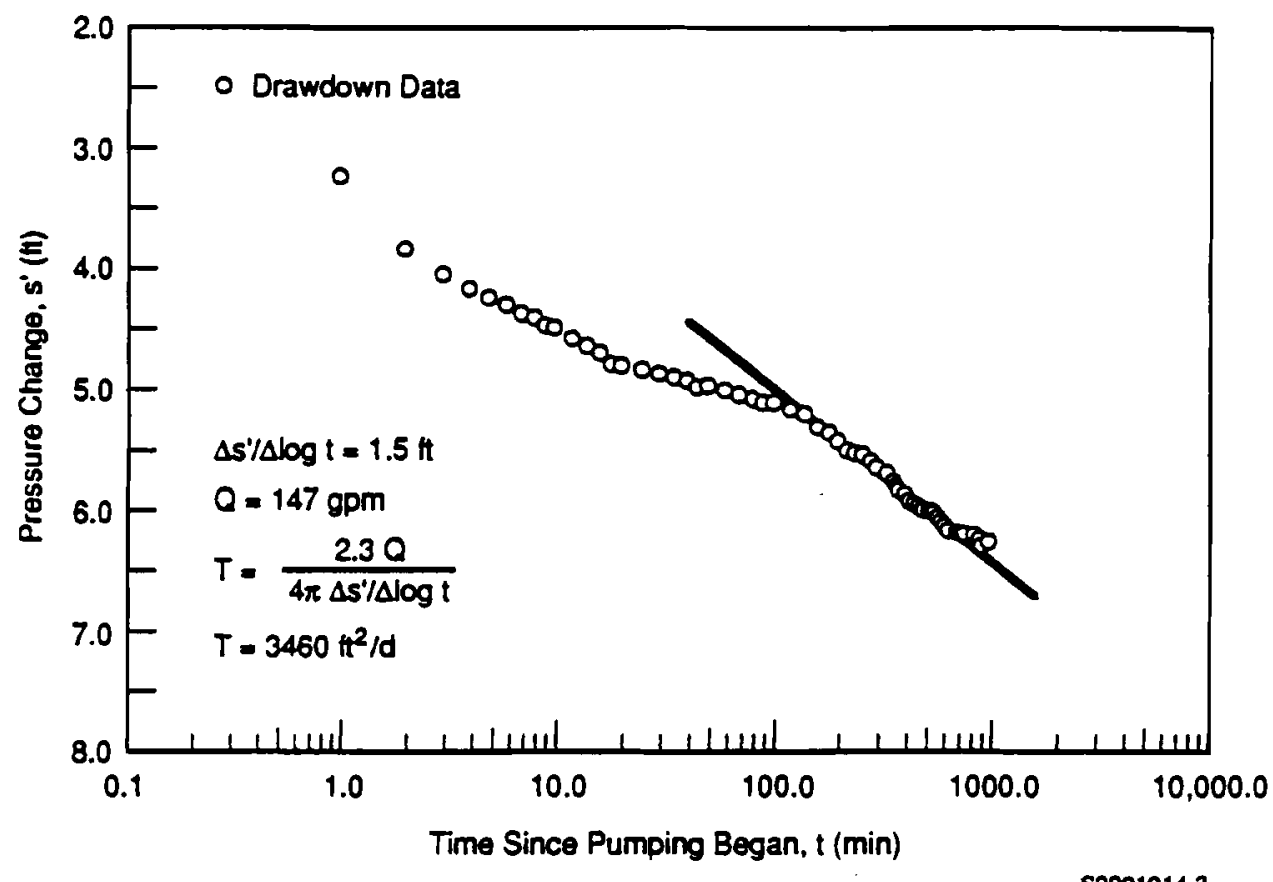

FIGURE B.3. Revised Analysis of Drawdown in We11 699-77-54

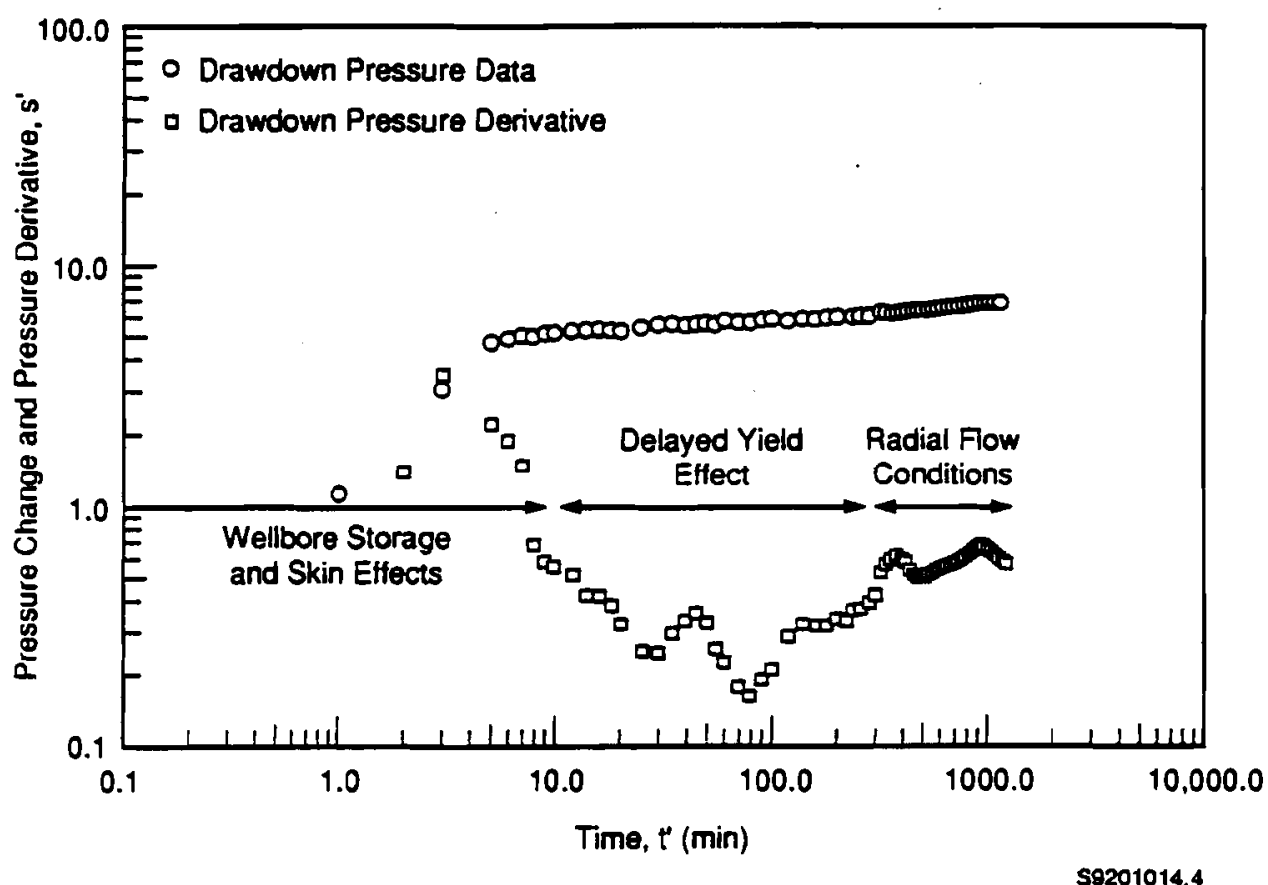

FIGURE B.4. Drawdown in Well 699-87-55 


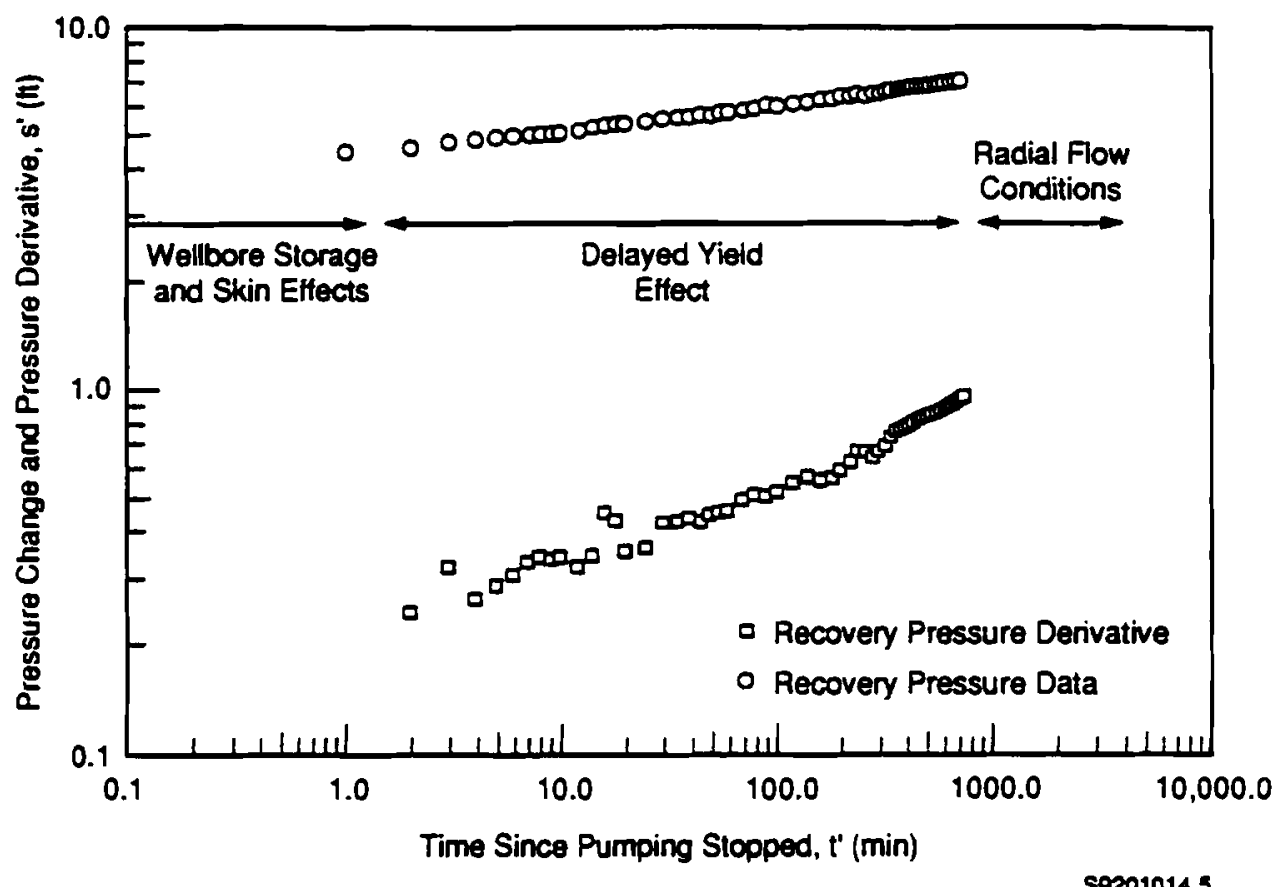

FIGURE B.5. Recovery for Well 699-87-55

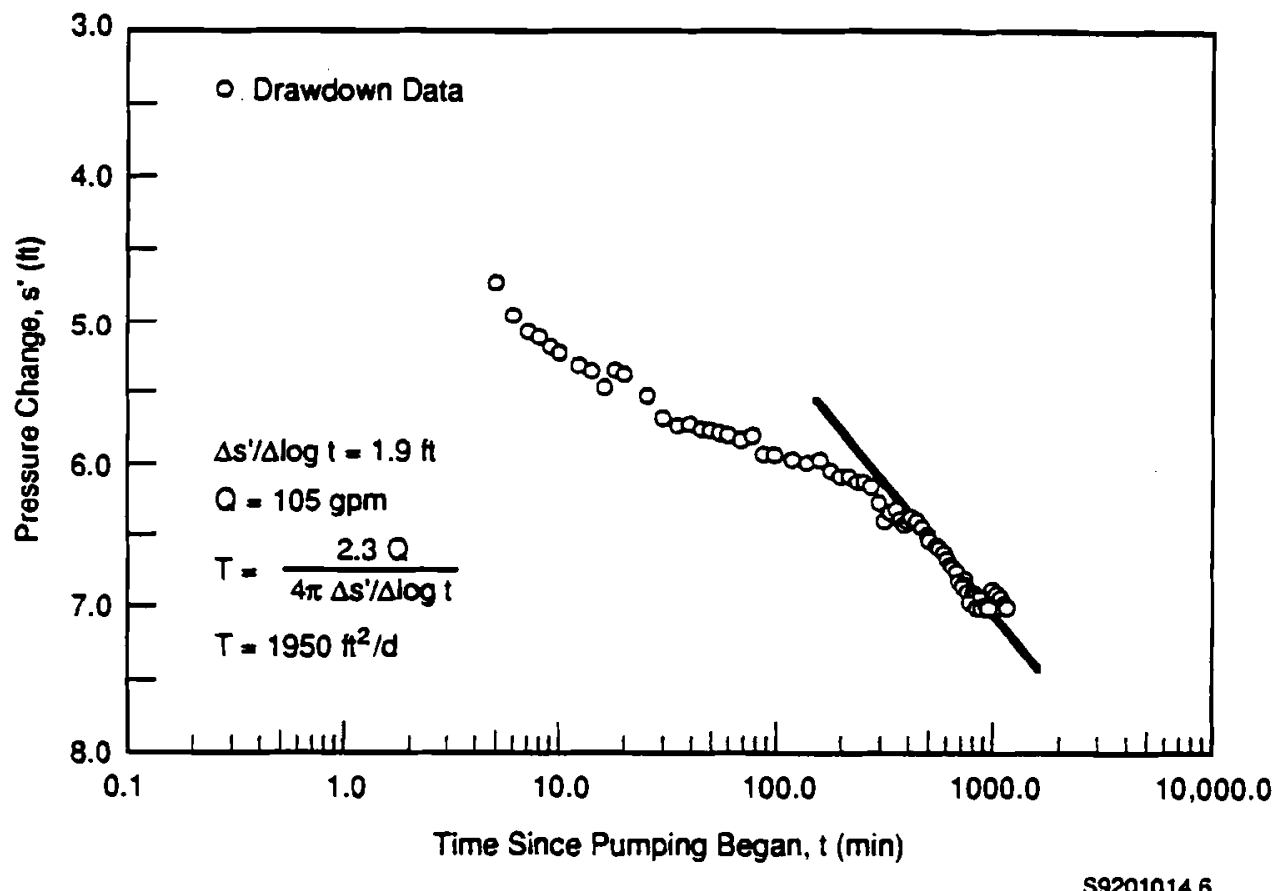

FIGURE B.6. Revised Analysis of Drawdown in Well 699-87-55

B. 8 


\section{$\underline{\text { References }}$}

Bierschenk, W. H. 1959. Aquifer Characteristics and Ground-Water Movement. HW-60601, General Electric Hanford Atomic Products Operation, Richland, Washington.

Bourdet, D., and A. Alagoa. 1984. "New Method Enhances Well Test Interpretation." World 0i1, September 1984, pp. 37-44.

Clark, D. G., and T. D. V. Golf-Racht. 1985. "Pressure Derivative Approach to Transient Test Analysjs: A High-Permeability North Sea Reservoir Example." Journal of Petroleum Technology, November 1985, pp. 2023-2038.

Cooper, H. H., Jr., and C. E. Jacob. 1946. "A Generalized Graphical Method for Evaluating Formation Contents and Summarizing Well Field History." Trans. Am. Geophys. Union 27:526-534.

Deju, R. A. 1974. The Hanford Field Testing Program. Report prepared for Atlantic Richfield Hanford Company, Richland, Washington.

Earlougher, R. C., Jr. 1977. Advances in Well Test Analysis. Monograph Volume 5, Henry L. Doherty Series, Society of Petroleum Engineers, Dallas, Texas.

Jacob, C. E. 1963. Determining the Permeability of Water-Table Aquifers. U.S. Geological Survey Water Supply Paper 1536-I.

Kipp, K. L., and R. D. Mudd. 1973. Collection and Analysis of Pump Test Data for Transmissivity Values. BNWL-1709, Battelle, Pacific Northwest Laboratories, Richland, Washington.

Weeks, E. P. 1978. "Aquifer Tests - The State of the Art in Hydrology." In Proceedings of the Invitational Well-Testing Symposium, October 19-21, 1977, Berkeley, California. LBL-7027, Lawrence Berkeley Laboratory, Berkeley, California. 


\section{APPENDIX C}

PROGRAM TEST RUNS 


\section{APPENDIX C}

\section{PROGRAM TEST RUNS}

Two sets of test runs of the WATER-VEL"M and WATDIS computer codes tested the combined programs' sensitivity to the inputs. Each test run used waterlevel data from December 1987 and 1989 and June 1989, 1990, and 1991. (These collection periods contained water-level data for all five wells in the network.) To evaluate the respective influence of each input parameter, the program inputs for hydraulic conductivity and the number of wells in the network were varied. The hydraulic conductivity inputs used were 40,50 and $60 \mathrm{ft} / \mathrm{d}$. Three of the wells providing hydraulic head input (699-78-62, 699-81-58 and 699-71-52) were deleted from the input file one at a time, leaving input from four wells for each run. Included here are the output files from each of the test runs. 
Output files for Varying the Hydraulic Conductivity

C. 2 


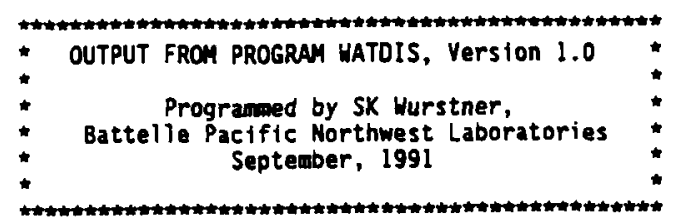

ECHO OF INPUT

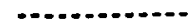

INPUT FILEMAME: a: jun9lk50.wVo OUTPUT FILEMAME: a:JUn91k50.out

TITLE: June 1991, all wells, k=50 $\begin{array}{llll}\text { COORDINATES OF POIMT I } & \text { EWE }-61129.00 & \text { NS }=86574.00 \\ \text { COORDINATES OF POINT } 2 & \text { EN- }-60266.00 & \text { NS }=87865.00\end{array}$

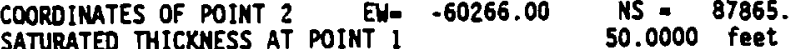
SATURATED THICXNESS AT POINT PRINT OUTPUT TO SCREEN NO 50.0000 feet $\begin{array}{lcl}\text { GROUMDUATER VELOCITY (FROM WATER-VEL) } & .2580 E+00 & \mathrm{ft} / \mathrm{daY} \\ \text { FLOH DIRECTION (DEGREES FROH + X-AXIS) } & 88.34 \\ \text { EFFECTIVE POROSITY OF THE AQUIFER } & .1100\end{array}$

\section{CALCULATED VaLUES}

DARCIAN VELOCITY (ANGLE OF 88.34 DEGREES) MOPUAL COMPONENT OF THE DARCIAN VELOCITY AREA OF THE SATURATED CROSS-SECTION ANGLE OF THE CROSS-SECTION (DEGREES FROM + X-AXIS) 54.07

$.2838 \mathrm{E}-01 \mathrm{ft} / \mathrm{day}$ $.1598 \mathrm{E}-01 \mathrm{ft} / \mathrm{day}$ $.735400 \mathrm{E}+05 \mathrm{ft}^{\wedge} 2$

GROUNDHATER OISCHARGE ACROSS THE AREA

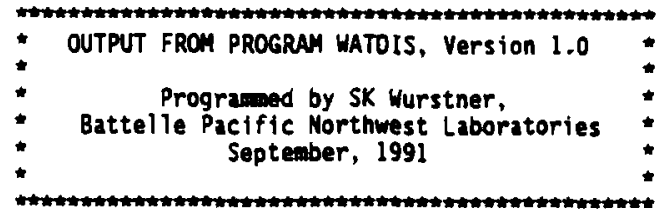

\section{ECHO OF INPUT}

INPUT FILENAME: a: JUn90k50.wO OUTPUT FILEMAME: a:jun90k50.out

TITLE: June 1990, all wells, $k=50$ COOROINATES OF POINT l NS - 86674.00 $\begin{array}{lll} & \\ & \end{array}$ SATURATED THICKNESS AT POINT $1 \quad 50.0000$ feet SATURATED THICKNESS AT POINT $2 \quad 50.0000$ feet PRINT OUTPUT TO SCREEN NO

GROUNDWATER VELOCITY (FROH HATER-VEL) $\quad .1920 E+00 \mathrm{ft} / \mathrm{day}$ FLON DIRECTION (DEGREES FRON + $X$-AXIS) 997.42 EFFECTIVE POROSITY OF THE AQUIFER

\section{CALCULATED VALUES}

DARCIAN VELOCITY (ANGLE OF 97.42 DEGREES) $.2112 E-01 \mathrm{ft} / \mathrm{day}$ MORMAL COMPONENT OF THE DARCIAN VELOCITY .1450E-01 $\mathrm{ft} / \mathrm{daY}$ AREA OF THE SATURATED CROSS-SECTION $.735400 E+05 \mathrm{ft}^{\wedge} 2$ ANGLE OF THE CROSS-SECTION (DEGREES FROH + X-AXIS) 54.07 GROUHDWATER DISCHARGE ACROSS THE AREA .106612E+04 ft^3/day 


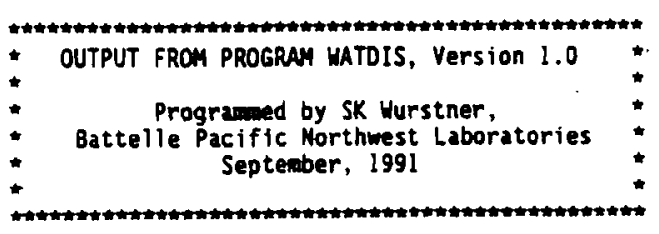

ECHO OF INPUT

INPUT FILEMAME: a:dec89k50.wvo

OUTPUT- FILEMAME: a:dec89k50.out

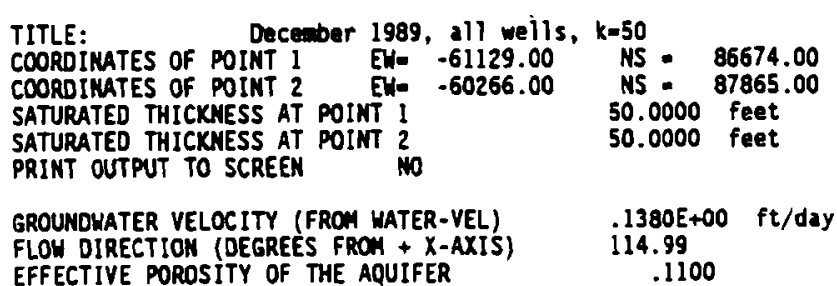

EFFECTIVE POROSITY OF THE AQUIFER

\section{CALCULATED VALUES}

DARCIAN VELOCITY (ANGLE OF 114.99 DEGREES) .1518E-01 $\mathrm{ft} / \mathrm{day}$ MORUAL COMPONENT OF THE DARCIAN VELOCITY . $3327 \mathrm{E}-01 \mathrm{ft} / \mathrm{day}$ AREA OF THE SATURATED CROSS-SECTION $.735400 E+05 \mathrm{ft}^{\wedge} 2$ ANGLE OF THE CROSS-SECTION (DEGREES FROM + X-AXIS) 54.07 GROUNOWATER DISCHARGE ACROSS THE AREA .975585E+03 $\mathrm{ft} \wedge 3 / \mathrm{day}$

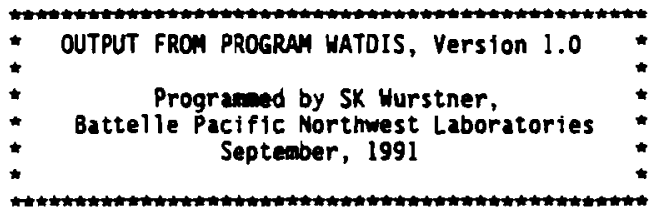

\section{ECHO OF INPUT}

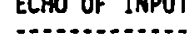

INPUT FILEMAME: a:jun89k50.wO OUTPUT FILERAME: a:jun89k50. out

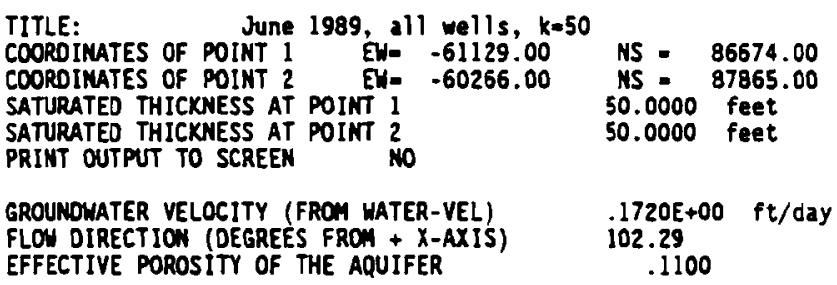

\section{CALCULATED VALUES}

\section{CALCULATED VALUES}

DARCIAN VELOCITY (ANGLE OF 102.29 DEGREES) MORMAL COMPOMENT OF THE DARCIAN VELOCITY AREA OF THE SATURATED CROSS-SECTIOH ANGLE OF THE CROSS-SECTION (DEGREES FRON + X-AXIS)

$.1892 \mathrm{E}-01 \mathrm{ft} / \mathrm{day}$ $.1411 \mathrm{E}-01 \mathrm{ft} / \mathrm{day}$ $735400 \mathrm{E}+05 \mathrm{ft} \wedge$ ?

GROUNDWATER DISCHARGE ACROSS THE AREA $.103751 E+04 \mathrm{ft} \wedge \mathrm{g} / \mathrm{day}$ 


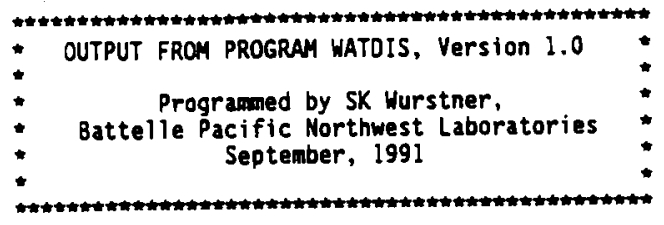

\section{ECHO OF INPUT}

INPUT FILEMAME: a: jUn9]k40.wNo OUTPUT FILEMAME: a: jun91k40. out

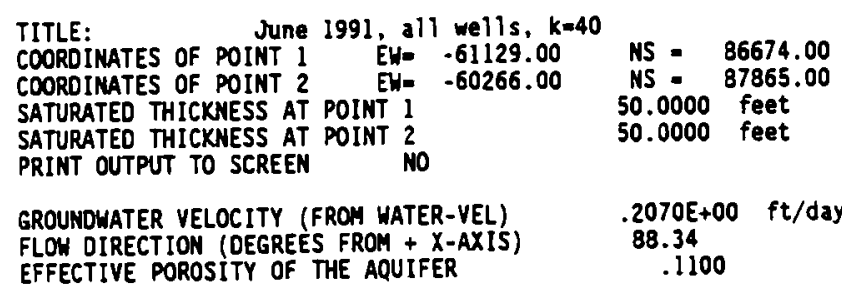

\section{CALCULATED VALUES}

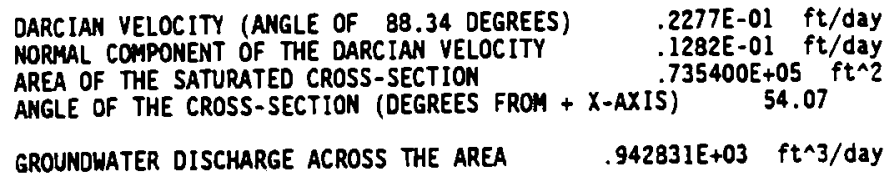

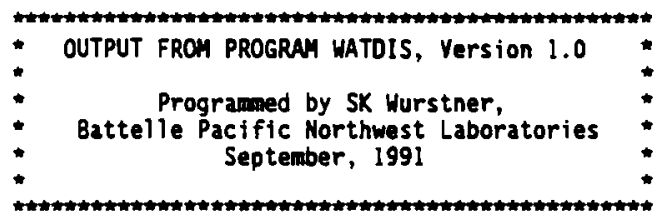

\begin{tabular}{|c|c|}
\hline \multicolumn{2}{|l|}{ ECHO OF INPUT } \\
\hline \multicolumn{2}{|l|}{ 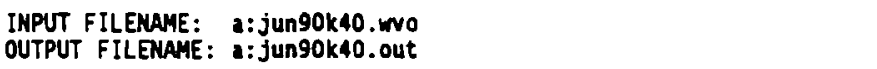 } \\
\hline \multicolumn{2}{|c|}{ 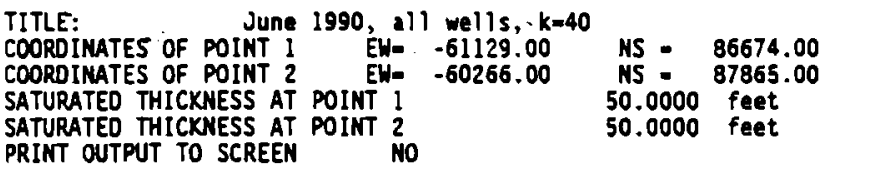 } \\
\hline $\begin{array}{l}\text { GROUNDWATER VELOCITY (FROH WATER-VEL) } \\
\text { FLOW DIRECTION (DEGREES FROH + X-AXIS) } \\
\text { EFFECTIVE POROSITY OF THE AQUIFER }\end{array}$ & $\begin{array}{l}.1530 E+00 \mathrm{ft} / \mathrm{day} \\
97.42 \\
\quad .1100\end{array}$ \\
\hline \multicolumn{2}{|l|}{ CALCULATED VALUES } \\
\hline $\begin{array}{l}\text { DARCIAN VELOCITY (ANGLE OF } 97.42 \text { DEGREES) } \\
\text { MORMAL COMPONENT OF THE DARCIAN VELOCITY) } \\
\text { AREA OF THE SATURATED CROSS-SECT ION } \\
\text { ANGLE OF THE CROSS-SECTIOH (DEGREES FROM + } X\end{array}$ & $\begin{array}{rl}.1683 E-01 & \mathrm{ft} / \mathrm{day} \\
.1155 \mathrm{E}-01 & \mathrm{ft} / \mathrm{day} \\
.735400 \mathrm{E}+05 \mathrm{ft} \mathrm{ft}^{-2} & \\
-\mathrm{AxIS}) & 54.07\end{array}$ \\
\hline GROUNDWATER DISCHARGE ACRDSS & $.849561 \mathrm{E}+03 \mathrm{ft \wedge} 3 / \mathrm{day}$ \\
\hline
\end{tabular}




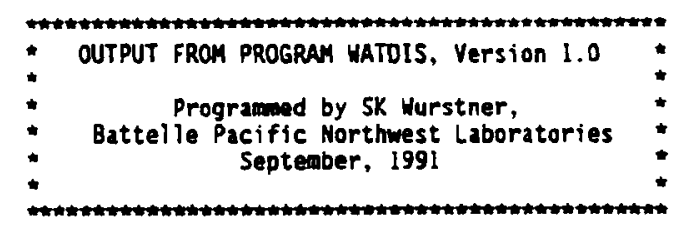

\begin{tabular}{|c|c|}
\hline \multicolumn{2}{|l|}{ ECHO OF INPUT } \\
\hline \multicolumn{2}{|l|}{$\begin{array}{l}\text { INPUT FILEMAME: } a \text { :dac89k40.wo } \\
\text { OUTPUT FILENAME: } a: \text { dec89k40. out }\end{array}$} \\
\hline $\begin{array}{l}\text { TITLE: } \\
\text { COORDINATES OF POINT 1 } \\
\text { COORDINATES OF POINT } 2 \\
\text { SATURATED THICXNESS AT POINT } 1 \\
\text { SATURATED THICKNESS AT POINT } 2 \\
\text { PRIKT OUTPUT TO SCREEN }\end{array}$ & $\begin{array}{l}k=40 \\
\text { NS }=\quad 86674.00 \\
\text { NS }=87865.00 \\
50.0000 \text { feet } \\
50.0000 \text { feet }\end{array}$ \\
\hline $\begin{array}{l}\text { GROUNOWATER VELOCITY (FRON WATER-VEL) } \\
\text { FLOW DIRECTION (DEGREES FRON + } X \text {-AXIS) } \\
\text { EFFECTIVE POROSITY OF THE AQUIFER }\end{array}$ & $\begin{array}{l}i 1100 E+00 \mathrm{ft} / \mathrm{day} \\
i 14.99 \\
.1100\end{array}$ \\
\hline \multicolumn{2}{|l|}{ CALCULATED VALUES } \\
\hline $\begin{array}{l}\text { DARCIAN VELOCITY (ANGLE OF } 114.99 \text { OEGREES) } \\
\text { NORUAL COMPONENT OF THE DARCIAN VELOCITY } \\
\text { AREA OF THE SATURATED CROSS-SECTIOH } \\
\text { ANGLE OF THE CROSS-SECTIOH (DEGREES FROM + }\end{array}$ & $\begin{array}{r}.1210 E-01 \mathrm{ft} / \mathrm{day} \\
.1057 \mathrm{E}-01 \mathrm{ft} / \mathrm{day} \\
.735400 \mathrm{E}+05 \mathrm{ft} / 2 \\
X-A X \mathrm{IS}) \quad 54.07\end{array}$ \\
\hline GROUNDWATER DISCHARGE ACROS & $.777640 \mathrm{E}+03 \mathrm{ft} \wedge 3 / \mathrm{day}$ \\
\hline
\end{tabular}

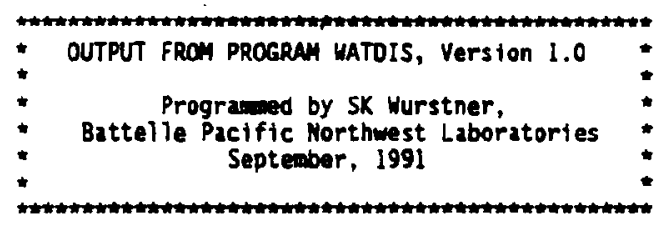

ECHO OF INPUT.

INPUT FILERAME: 2:jun89k40.wvo

OUTPUT FILEMAME: a: junB9k40.out

TITLE: JUne 1989, all wells, $k=40$

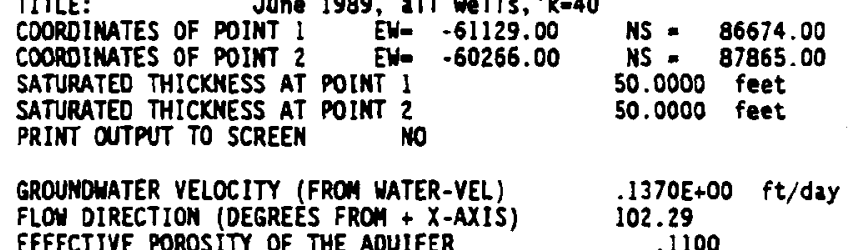

EFFECTIVE POROSITY OF THE AQUIFER

\section{CALCULATEO VALUES}

DARCIAN VELOCITY (ANGLE OF 102.29 DEGREES) .1507E-01 $\mathrm{ft} / \mathrm{day}$ $\begin{array}{ll}\text { NORMAL COMPONERT OF THE OARCIAN VELOCITY } & .1124 E-01 \mathrm{ft} / \mathrm{daY} \\ \text { AREA OF THE SATURATEO CROSS-SECTIOH } & .735400 E+05 \mathrm{ft} / 2\end{array}$ AREA OF THE SATURATEO CROSS-SECTION ANGLE OF THE CROSS-SECTION (DEGREES FROM $+x$-AXIS)

GROUNDWATER OISCHARGE ACROSS THE AREA $.826391 E+03 \mathrm{ft \wedge} 3 / \mathrm{day}$ 


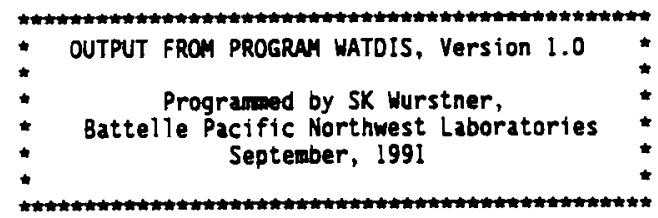

ECHO OF INPUT

IMPUT FILENAME: a: Jun91k60.wvo OUTPUT FILERAME: a:jun91k60. out

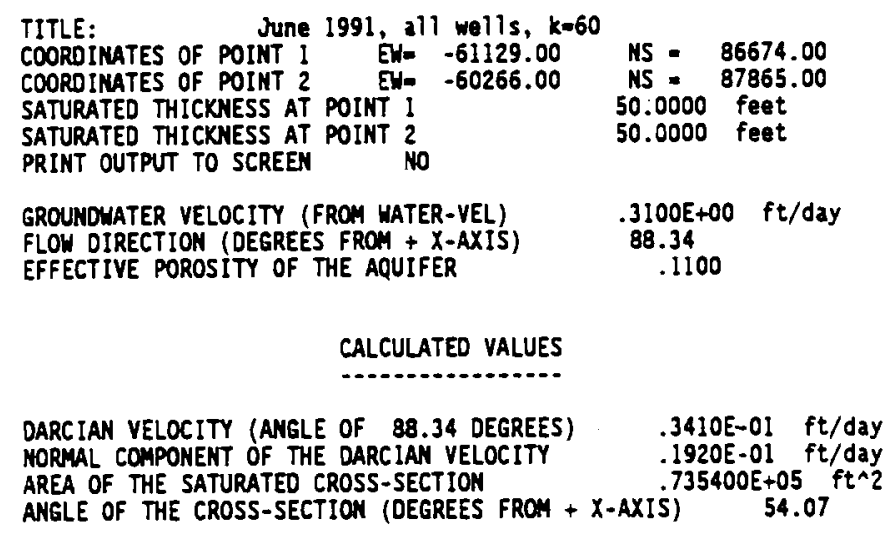

GROUNOWATER DISCHARGE ACROSS THE AREA .141197E+04 $\mathrm{ft}^{\wedge} 3 / \mathrm{day}$

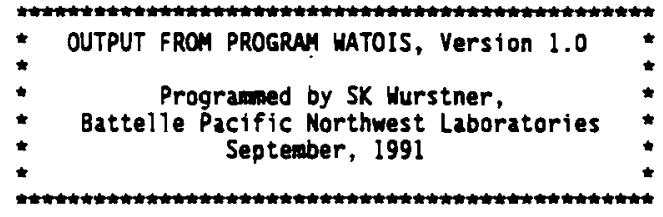

\section{ECHO OF INPUT}

IMPUT FILEMAME: a: Jun90k60.wVo

OUTPUT FILERAME: a: jun90k60. Out

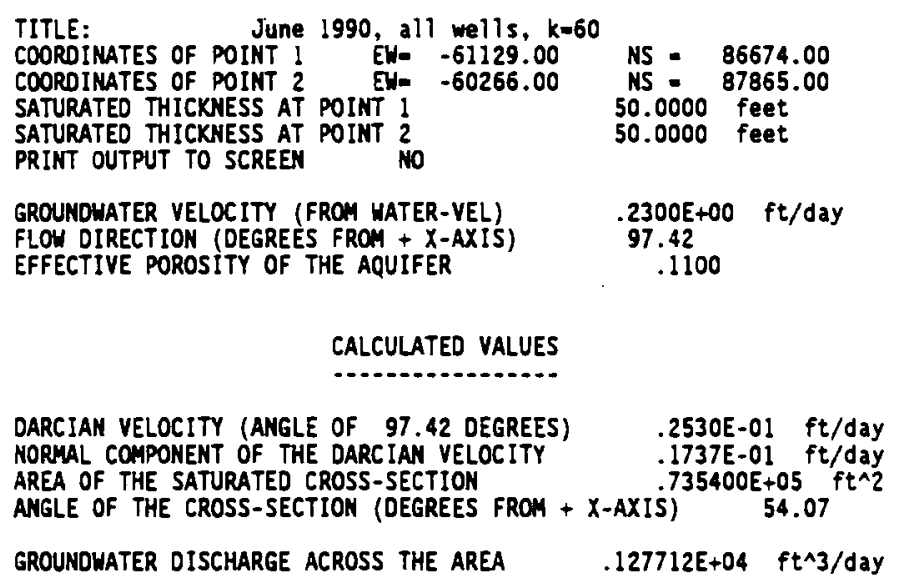




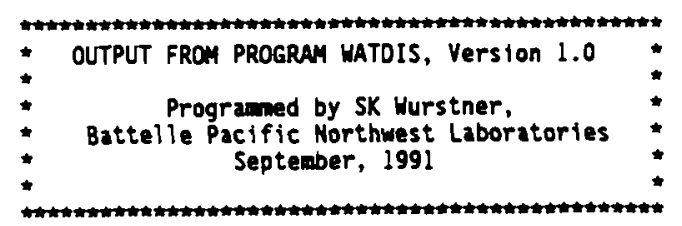

ECHO OF INPUT

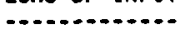

INPUT FILEMAME: a:dec89k60.wo

OUTPUT FILEMAME: a:dec89k60. out

TITLE: December 1989, all wells, k=60

COORDINATES OF POINT I EWE -61229.00 NS $=86674.00$ COORDINATES OF POINT 2 EW- -60266.00 NS $=87865.00$

SATURATED THICXNESS AT POINT

SATURATED THICXNESS AT POINT 2

PRINT OUTPUT TO SCREEM

2

50.0000 feet

50.0000 feet

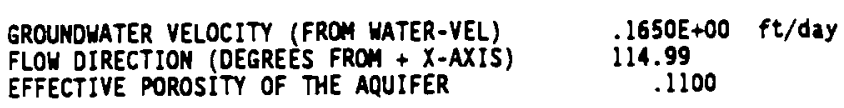

CALCULATED VALUES

DARCIAN VELOCITY (ANGLE OF 114.99 DEGREES) MORMAL COMPONENT OF THE DARCIAY VELOCITY AREA OF THE SATURATED CROSS-SECTION ANGLE OF THE CROSS-SECTION (DEGREES FROM $+X$-AXIS)

$.1815 E-01 \mathrm{ft} /$ day $.1586 \mathrm{E}-0 \mathrm{l} \mathrm{ft} / \mathrm{day}$ $.735400 \mathrm{E}+05 \mathrm{ft}^{\wedge} 2$

GROUNDWATER DISCHARGE ACROSS THE AREA

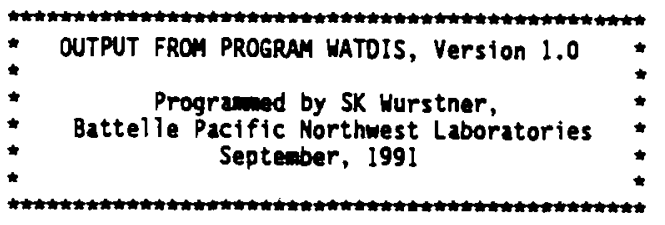

\section{ECHO OF IMPUT}

INPUT FILERAME: a:jUn89k60.wo OUTPUT. FILEMAME: a:jun89k60. out

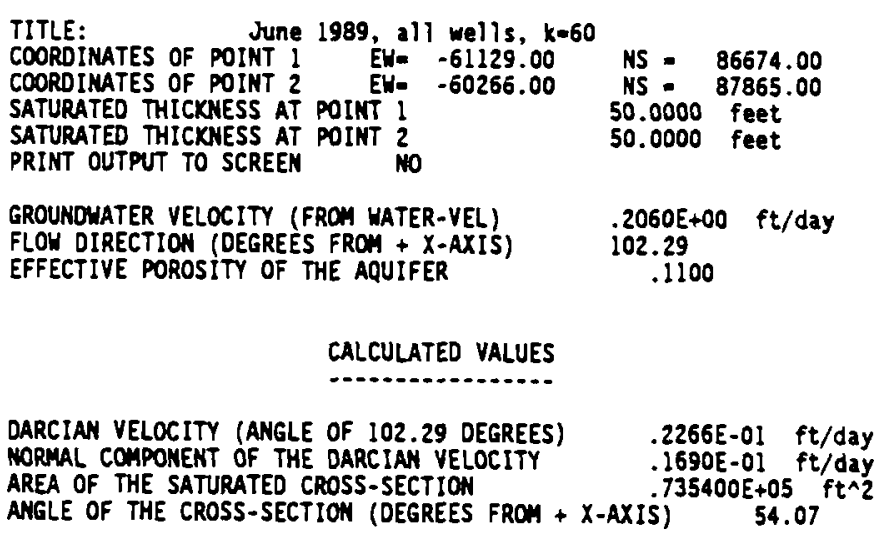

GROUNDWATER DISCHARGE ACROSS THE AREA .124260E+04 ft^3/day 
Output files for Varying the We 11 Network

$$
\text { C.9 }
$$




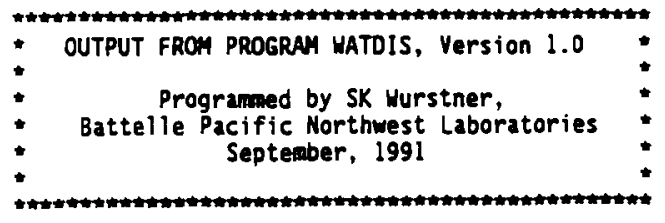

ECHO OF INPUT

INPUT FILEMAME: a:jUn91-71.wNo

OUTPUT FILEMAME: a:jun91-71. OUt

TITLE: $\quad$ lune 1991, ainus wel1-71-52, $k=50$

COORDINATES OF POINT 1 EY- -61129.00 NS $=86674.00$

COORDINATES OF POINT 2 EY- -60266.00 NS $=87865.00$

SATURATED THICKMESS AT POINT 1 50.0000 feet

SATURATED THICKMESS AT POINT 2 50.0000 feet

PRINT OUTPUT TO SCREEN NO

GROUNDWATER VELOCITY (FROM HATER-VEL) .3110E+00 $\mathrm{ft} / \mathrm{daY}$

FLON OIRECTION (DEGREES FROM $+X$-AXIS) 96.96

EFFECTIVE POROSITY OF THE AQUIFER

\section{CALCULATED VALUES}

DARCIAN VELOCITY (ANGLE OF 96.96 DEGREES) .3421E-01 ft/day MORMAL COMPONEHT OF THE DARCIAN VELOCITY .2328E-01 ft/day AREA OF THE SATURATED CROSS-SECTION .735400E+05 $\mathrm{ft}^{\wedge} 2$ ANGLE OF THE CROSS-SECTION (DEGREES FRON $+x$-AX1S) 54.07

GROUNDHATER OISCHARGE ACROSS THE AREA .171214E+04 $\mathrm{ft} \wedge 3 / \mathrm{day}$

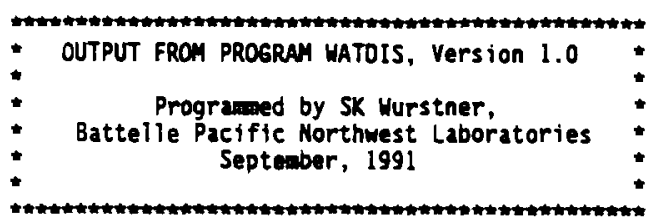

\section{ECHO OF INPUT}

INPUT FILEMAME: a: jun90-71. wvo

OUTPUT FILEMAME: a: JUn90-71. Out

TITLE: June 1990, minus well 71-52.

COOROINATES OF POIMT I EY. -61129.00

COORDINATES OF POINT 2 EH- -60266.00

SATURATED THICKMESS AT POINT

SATURATED THICKNESS AT POINT 2

PRINT OUTPUT TO SCREEN

HO

NS -86674.00

NS: 87865.00

50.0000 feet

50.0000 feet

GROUNDHATER VELOCITY (FROM WATER-VEL)

FLOH DIRECTION (DEGREES FROM + X-AXIS)

EFFECTIYE POROSITY OF THE AQUIFER

$.2410 E+00 \mathrm{ft} / \mathrm{day}$

105.13

.1100

\section{CALCULATED VALUES}

DARCIAN VELOCITY (ANGLE OF 105.13 DEGREES)

NORMAL COMPONENT OF THE DARCIAN VELOCITY

AREA OF THE SATURATED CROSS-SECTION

$.2651 E-01 \mathrm{ft} / \mathrm{day}$

2062E-01 ft/day

ANGLE OF THE CROSS-SECTION (DEGREES FROM $+x$-AXIS) 54.07

GROUMDHATER DISCHARGE ACROSS THE AREA

$.151630 \mathrm{E}+04 \mathrm{ft}$ f`3/day

C. 10 


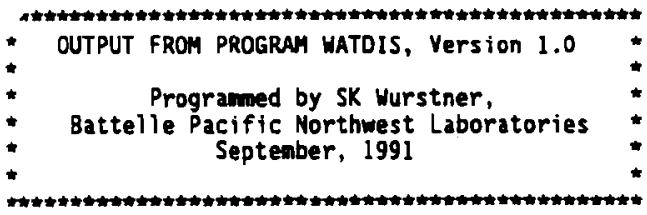

\section{ECHO OF INPUT}

INPUT FILEMAME: a:dec89-71. wo OUTPUT. FILEMAME: a: dec89-71. out

\begin{tabular}{|c|c|}
\hline $\begin{array}{l}\text { TITLE: } \\
\text { COORDINATES OF POINT } 1 \\
\text { COORDINATES OF POINT } 2 \\
\text { SATURATED THICKNESS AT POINT } 1 \\
\text { SATURATED THICKNESS AT POINT } 2 \\
\text { PRINT OUTPUT TO SCREEN }\end{array}$ & $\begin{array}{l}71-52, k=50 \\
\text { NS: } 86674.00 \\
\text { NS: } 87865.00 \\
50.0000 \text { feet } \\
50.0000 \text { feet }\end{array}$ \\
\hline $\begin{array}{l}\text { GROUNOWATER VELOCITY (FROM WATER-VEL) } \\
\text { FLOW DIRECTION (DEGREES FROH + X-AXIS) } \\
\text { EFFECTIVE POROSITY OF THE AQUIFER }\end{array}$ & $\begin{array}{l}1760 E+00 \mathrm{ft} / \text { day } \\
118.73 \\
.1100\end{array}$ \\
\hline \multicolumn{2}{|l|}{ CALCULATED VALUES } \\
\hline $\begin{array}{l}\text { DARCIAN YELOCITY (ANGLE OF } 118.73 \text { DEGREES) } \\
\text { NORMAL COMPONENT OF THE DARCIAN VELOCITY } \\
\text { AREA OF THE SATURATED CROSS-SECTION } \\
\text { ANGLE OF THE CROSS-SECTION (DEGREES FROM + }\end{array}$ & $\begin{array}{r}.1936 \mathrm{E}-01 \mathrm{ft} / \mathrm{day} \\
.1750 \mathrm{f}-01 \mathrm{ft} / \mathrm{day} \\
.735400 \mathrm{E}+05 \mathrm{ft} \mathrm{ft}^{\wedge} \\
-\mathrm{AX} 15)^{54.07}\end{array}$ \\
\hline OUNDYATER OISCHARGE ACROSS THE AREA & $.128672 E+04 \mathrm{ft \wedge} 3 / \mathrm{day}$ \\
\hline
\end{tabular}

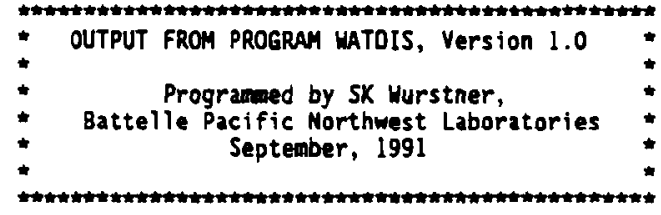

\section{ECHO OF INPUT}

INPUT FILEMAME: a: Jun89-71.wvo

OUTPUT FILEMAME: a:Jun89-71. out

\begin{tabular}{|c|c|c|c|}
\hline $\begin{array}{l}\text { TITLE: } \\
\text { COORDIMATES OF POINT } 1 \\
\text { COORDIMATES OF POINT } 2 \\
\text { SATURATED THICXNESS AT } \\
\text { SATURATED THICKNESS AT } \\
\text { PRINT OUTPUT TO SCREEN }\end{array}$ & $\begin{array}{l}\text { 1989, minus wel1 } 71-52 \text {, } \\
\text { EW- }-61129.00 \\
\text { EW- }-60266.00 \\
\text { POINT } 1 \\
\text { POINT } 2 \\
\text { NO }\end{array}$ & $\begin{array}{l}\quad k=50 \\
\text { N5 }= \\
\text { N5 }= \\
50.0000 \\
50.0000\end{array}$ & $\begin{array}{l}86674.00 \\
87865.00 \\
\text { feet } \\
\text { feet }\end{array}$ \\
\hline $\begin{array}{l}\text { GROUNDWATER YELOCITY } \\
\text { FLOW DIRECTIOW (DEGRE } \\
\text { EFFECTIVE POROSITY OF }\end{array}$ & $\begin{array}{l}+x-A X I S \\
\text { IFER }\end{array}$ & $\begin{array}{c}.2050 E+0 \\
107.44 \\
.1100\end{array}$ & 0 \\
\hline
\end{tabular}

\section{CALCULATED VALUES}

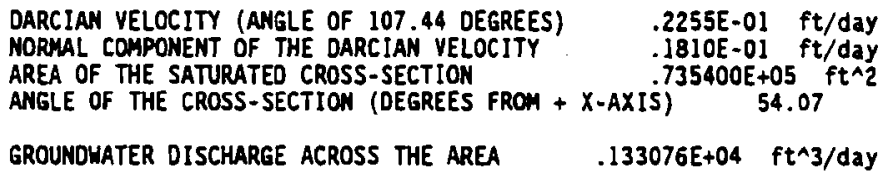




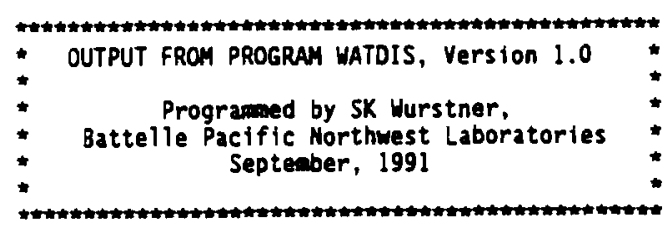

\section{ECHO OF INPUT}

INPUT FILEMAME: a:jungl-78.wo OUTPUT FILEMAME: a:jungl-78.out

\begin{tabular}{|c|c|c|c|}
\hline $\begin{array}{l}\text { JITLE: } \\
\text { COORDINATES OF POINT } \\
\text { COORDIMATES OF POINT } 2 \\
\text { SATURATED THICKNESS AT } \\
\text { SATURATED THICKNESS AT } \\
\text { PRINT OUTPUT TO SCREEN }\end{array}$ & $\begin{array}{l}1991 \text {, minus we11 78-62, } \\
\text { EN- }-61129.00 \\
\text { EN= }-60266.00 \\
\text { POINT } \frac{1}{2} \\
\text { POINT 2 } \\
\text { NO }\end{array}$ & $\begin{array}{l}\text { 2. } k=50 \\
\text { NS }= \\
\text { HS }= \\
50.0000 \\
50.0000\end{array}$ & $\begin{array}{l}86674.00 \\
87865.00 \\
\text { feet } \\
\text { feet }\end{array}$ \\
\hline $\begin{array}{l}\text { GROUNDWATER VELOCITY } \\
\text { FLOW DIRECTION (DEGR } \\
\text { EFFECTIVE POROSITY O }\end{array}$ & $\begin{array}{l}\text { (FE-VEL) } \\
X X-A X I S) \\
\text { (FER }\end{array}$ & $\begin{array}{l}.2610 E+0 \\
80.35 \\
.1100\end{array}$ & $t /$ day \\
\hline
\end{tabular}

\section{CALCULATED VALUES}

DARCIAM VELOCITY (AMGLE OF 80.35 DEGREES) MORMAL COMPONENT OF THE DARCIAN VELOCITY AREA OF THE SATURATED CROSS-SECTION AMGLE OF THE CROSS-SECTION (DEGREES FROM + X-AXIS) 54.07 $.1271 \mathrm{E}-01 \mathrm{ft} / \mathrm{day}$

GROUNOWATER OISCHARGE ACROSS THE AREA

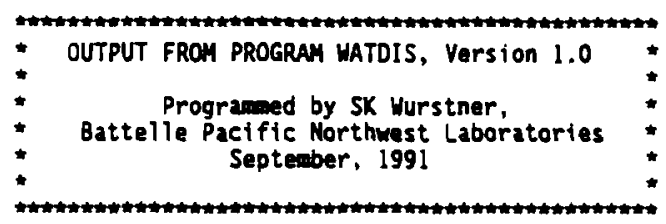

\section{ECHO OF INPUT}

INPUT FILEMAME: a:jUn90-78.wNo OUTPUT FILEMAME: a:jun90-78. out

TITLE: COORDIMATES OF POIUne 1990, winus will $78-6$ COOROIMATES OF POINT 2 EH- -60266.00 NS $=87865.00$ SATURATED THICKMESS AT POINT I 50.0000 feet SATURATED THICKNESS AT POINT 2
PRINT OUTPUT TO SCREEN no

50.0000 feet

GROUMDHATER VELOCITY (FROM YATER-VEL)

FLON DIRECTION (DEGREES FRON $+X$-AXIS)

EFFECTIVE POROSITY OF THE AQUIFER

$$
\begin{aligned}
& .1920 E+00 \mathrm{ft} / \mathrm{day} \\
& 78.69 \\
& .1100
\end{aligned}
$$

\section{CALCULATED VALUES}

DARCLAN VELOCITY (ANGLE OF 78.69 DEGREES)

MORMAL COMPONENT OF THE DARCIAN VELOCITY

AREA OF THE SATURATED CROSS-SECTIOH

$.2112 E-01 \mathrm{ft} / \mathrm{day}$

ANGLE OF THE CROSS-SECTION (DEGREES

8798E-02 ft/day

GROUHOWATER DISCHARGE ACROSS THE AREA $.735400 \mathrm{E}+05 \mathrm{ft} \mathrm{ft}^{\wedge}$ 


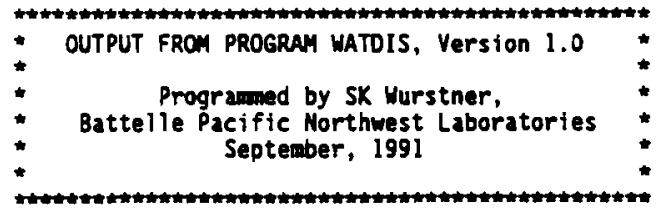

\section{ECHO OF INPUT}

IMPUT FILEHAME: a:dec89-78.wo

OUTPUT FILENAME: 2:dec89-78. out

TITLE: COORDINATES OF POINT 1 EW- -61129.00 COORDIMATES OF POINT 2 EW- -60266.00 SATURATED THICXNESS AT POINT I SATURATED THICXNESS AT POINT 2 PRINT OUTPUT TO SCREEH No

8-62, $k=50$

NS $=86674.00$

NS - 87865.00

50.0000 feet

50.0000 feet

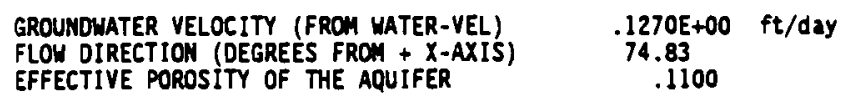

\section{CALCULATEO VALUES}

DARCIAN VELOCITY (ANGLE OF $\mathbf{7 4 . 8 3}$ DEGREES) NORMAL COMPONENT OF THE DARCIAN VELOCITY AREA OF THE SATURATED CROSS-SECTION ANGLE OF THE CROSS-SECTION (DEGREES FRON $+x$-AXIS)

$\quad 54.07$

GROUNOWATER DISCHARGE ACROSS THE AREA

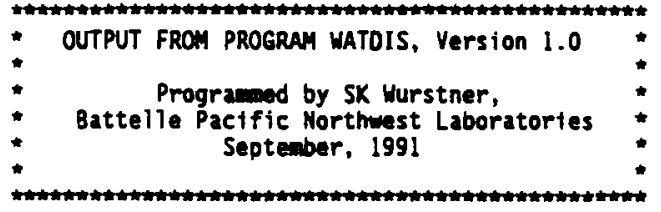

\section{ECHO OF IHPUT}

IMPUT FILENAME: a:Jun89-78.wo

OUTPUT FILEMAME: a:JUn89-78. out

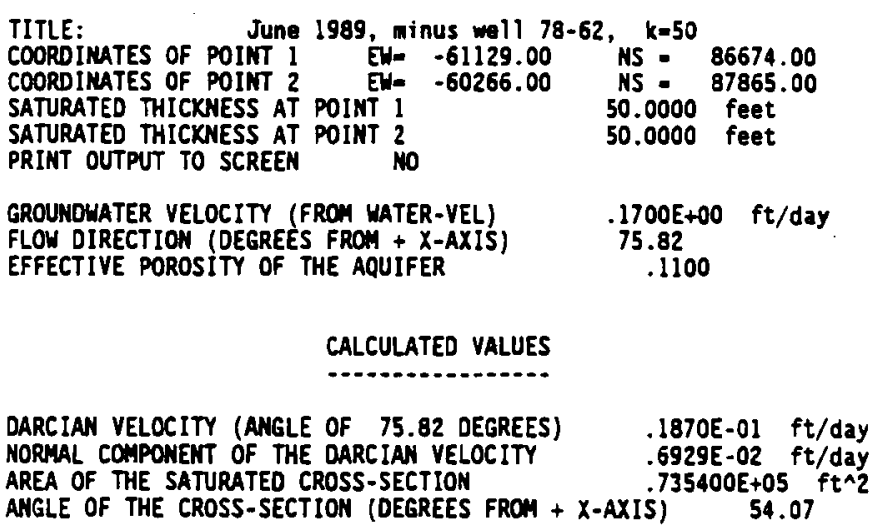

GROUMDHATER DISCHARGE ACROSS THE AREA 


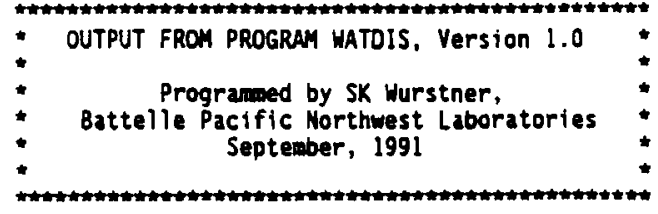

\section{ECHO OF INPUT}

IMPUT FILERAME: a:jung1-81.wvo OUTPIT FILEMAME: a:JUn91-81 . out

TITLE: June 1991, ninus we11.81-58, $k=50$

COORDIMATES OF POINT I EV- -61129.00 COORDIMATES OF POINT 2 EN- $\quad-60266.00$ SATURATED THICKMESS AT POINT 1 SATURATED THICKNESS AT POINT 2 PRINT OUTPUT TO SCREEN

MO

NS = 86674.00

NS - 87865.00

50.0000 feet

50.0000 feet

$.2560 \mathrm{E}+00 \mathrm{ft} / \mathrm{day}$
88.46

.1100

FLOW DIRECTION (DEGREES FROA + X-AXIS)

EFFECTIVE POROSITY OF THE AQUIFER

\section{CALCULATED VALUES}

CALCU....................

DARCIAN VELOCITY (ANGLE OF 88.46 DEGREES) MORUAL COMPOMEMT OF THE DARCIAN VELOCITY AREA OF THE SATURATED CROSS-SECTIOH ANGLE OF THE CROSS-SECTION (DEGREES FROM + X-AXIS)

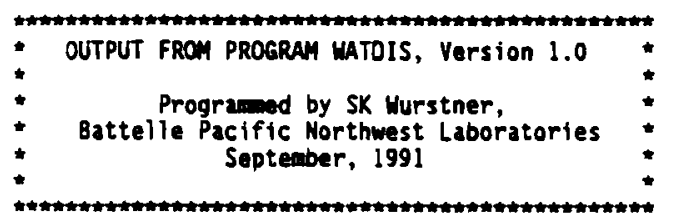

\section{ECHO OF INPUT}

INPUT FILEMAME: a:jUn90-81.wNo OUTPUT FILENAME: 2 :JUn90-81. out

TITLE: June 1990, winus well 81-58, $k-50$ COORDIRATES OF POINT 1 EY- -61129.00 NS - 86674.00 COOROIMATES OF POINT 2 EW- -60266.00 NS $=87865.00$ SATURATED THICKMESS AT POINT SATURATED THICXYESS AT POINT ? PRINT OUTPUT TO SCREEH NO 50.0000 feet 50.0000 feet

GROUNOUATER VELOCITY (FROM WATER-VEL) FLOW DIRECTION (DEGREES FRON + X-AXIS) EFFECTIVE POROSITY OF THE AQUIFER

\section{CALCULATED VALUES}

DARCIAN VELOCITY (ANGLE OF 92.60 DEGREES) MORMAL COMPONENT OF THE DARCIAN VELOCITY AREA OF THE SATURATED CROSS-5ECTION ANGLE OF THE CROSS-SECTION (DEGREES FROM $+x$-AXIS) $.735400 \mathrm{E}+05 \mathrm{ft} \wedge 2$ GROUNDHATER DISCHARGE ACROSS THE AREA $.122442 \mathrm{E}+04 \mathrm{ft} \wedge 3 / \mathrm{day}$ 


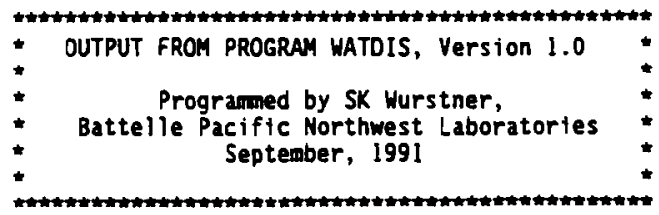

ECHO OF INPUT

INPUT FILERAME: a:dec89-81.wNo

OUTPUT. FILENAME: a:dec89-81. out

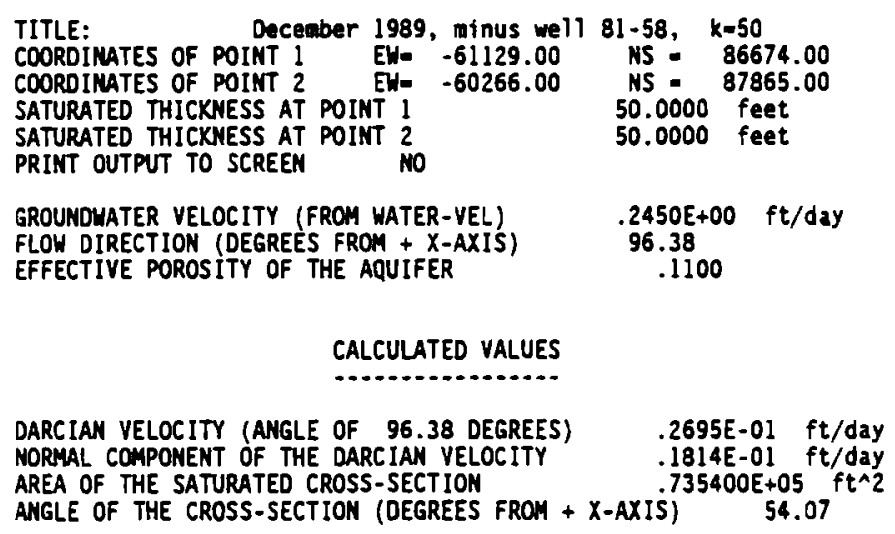

GROUMDHATER DISCHARGE ACROSS THE AREA .133403E+04 $\mathrm{ft}^{\wedge} 3 / \mathrm{day}$

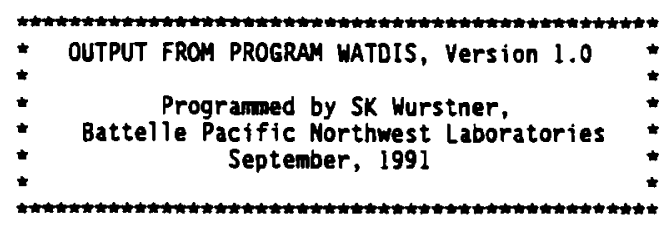

\section{ECHO OF INPUT}

INPUT FILERAME: a: JUn89-81.wVo

OUTPUT FILENAME: a:jun89-81. out

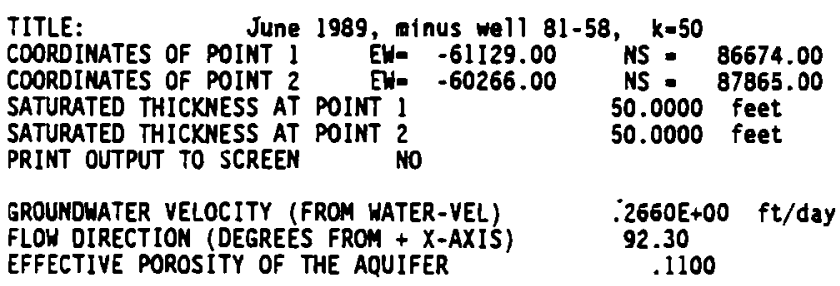

\section{CALCULATED VALUES}

DARCIAN VELOCITY (ANGLE OF 92.30 DEGREES) NORYAL COMPONENT OF THE DARCIAN VELOCITY

AREA OF THE SATURATED CROSS-SECTIOH ANGLE OF THE CROSS-SECTION (DEGREES FROM + X-AXIS) 54.07 GROUMDHATER DISCHARGE ACROSS THE AREA 


\section{DISTRIBUTION}

No. of

Copies

OFFSITE

12 DOE/Office of Scientific and Technical Information

\section{ONSITE}

3 DOE Richland Field office

R. D. Hildebrand A5-55

$H$. R. Trumble (2) A6-55

11 Westinghouse Hanford Company
M. P. Connelly H4-14
B. L. Curn
$\mathrm{XO}-21$
R. P. Henckel (2) $\mathrm{H} 4-55$
G. S. Hunacek $\mathrm{X} 0-41$
C. J. Perkins
$\times 0-21$
D. J. Watson (5) $\times 0-41$

No. of

Copies

16 Pacific Northwest Laboratory

P. G. Doctor

K6-96

T. J Gilmore (3) K6-96

G. V. Last

K6-96

T. L. Liikala K6-96

D. R. Newcomer K6-96

F. A. Spane K6-96

S. K. Wurstner K6-77 Publishing Coordination Technical Files (5)

\section{Routing}
R. M. Ecker
MSL/Sequim
J. W. Falco
$\mathrm{K} 6-78$
M. J. Graham
$\mathrm{K} 6-80$
R. L. Skaggs
$\mathrm{K} 6-77$
P. C. Hays (last) K6-86 